\title{
TALES OF POSSESSION
}

A Study of Possession in the Novels of A. S. Byatt and John Fowles

By

Samantha Edwards

A thesis submitted to the Victoria University of Wellington in fulfilment of the requirements for the degree of Master of Arts in English Literature

Victoria University of Wellington

2017 


\begin{abstract}
This thesis focuses on four works: John Fowles's The Collector and The French Lieutenant's Woman, and A. S. Byatt's The Game and Possession: A Romance. The French Lieutenant's Woman and Possession have frequently been treated together in academic criticism as Possession was a deliberate response to the former. I have extended this pairing because these four works are built around the idea of 'possession'. While most critical discussions consider the notion of 'possession' as one theme among many, this thesis proposes that 'possession' dominates the characterisations in these works.

The starting point for my argument is Jean Baudrillard's theory of possession as outlined in his chapter "The System of Collecting". Baudrillard proposes that "[p]ossession cannot apply to an implement" (7). To possess an object it must undergo an "abstractive operation" (7) until it is "divested of its function and made relative to a subject" (8). This thesis translates that subject-object relationship to characters, where one character is the possessor, another the possessed. While the possessive drive can take on multiple forms, in these works romantic, erotic, intellectual, and creative desires come to the fore. The Collector and The Game involve a one-on-one dynamic. The first is one man's attempt to romantically possess his female obsession, the second is one woman's attempt to creatively appropriate and possess her sister. Both novels are preludes to the more complex examinations of possessive intent in the novelists' later work. In The French Lieutenant's Woman Charles Smithson undertakes an erotic and romantic quest to possess Sarah Woodruff. Along with this is the socially possessed Ernestina Freeman. The contemporary scholars in Possession all compete to intellectually and creatively possess the Victorian poets Randolph Henry Ash and Christabel LaMotte. The possessive parties in these works attempt to stabilise their projections under the delusion of reciprocity. Only the title of Byatt's novel hints literally at 'possession', but in all of these works 'possession' reveals the nature of relationships between human beings.
\end{abstract}


Edwards ii

Acknowledgements

To my supervisors, Charles Ferrall and Heidi Thomson, I am thankful for your guidance while writing this thesis, and during this year of personal growth.

I am grateful to my parents, Bob and Susan Edwards, for their unwavering support. 
Edwards iii

\section{Contents}

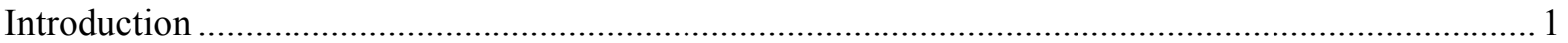

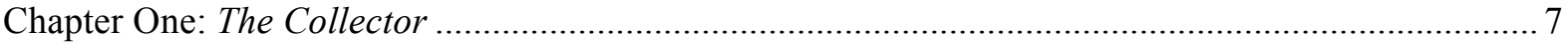

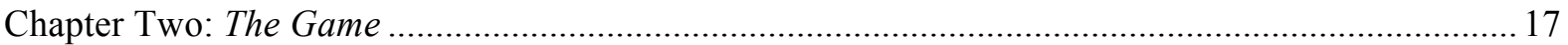

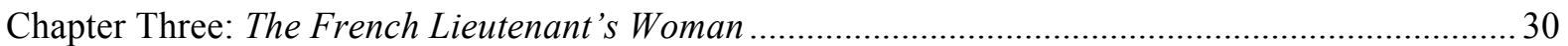

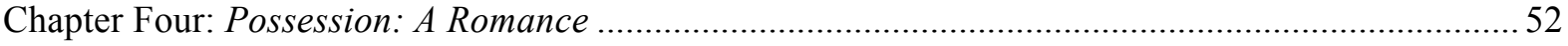

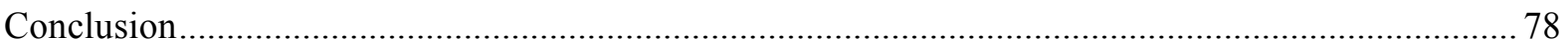

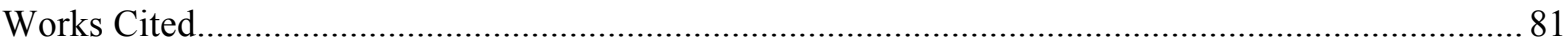




\section{Introduction}

In relationships people are driven by either a desire to meet others as equals, with some sense that they too exist as subjects, or by a need to objectify and possess them. To possess or to not possess is a question central to the character relations in the novels of A.S. Byatt and John Fowles, particularly the four considered in this thesis: The Collector (1963) and The French Lieutenant's Woman (1969) [hereafter TFLW] by Fowles, and The Game (1967) and Possession: A Romance (1990) [hereafter Possession] by Byatt. I dedicate one chapter to each of these novels.

This thesis began with the more general idea of 'collecting' in literature, but the project developed into an examination of possession because the act of collecting is a key symptom of the impulse to possess. Even if "the reality of another human being can never be possessed in terms of an object relationship" this does not mean that the subject-object relation for non-human examples does not aptly describe how one desires to possess others (Binns 26). To establish my argument I draw from what Robert Wendorf calls the "founding document in the literature of collecting", Jean Baudrillard's "The System of Collecting" (Wendorf 7). Baudrillard argues that the subject-object relation is a possessive process undertaken via an "abstractive operation" (Baudrillard 7). In this context, the term "abstraction" aligns with the second definition of the word in the OED: "the action of taking something away; the action or process of withdrawing or removing something from a larger quantity or whole" (“abstraction"). The "abstractive operation" describes the object being "divested of its function and made relative to a subject" (7). Baudrillard provides the example of a machine. If the machine is functioning with its intended purpose then it is a utility; the relationship between the machine and the user is reciprocal (8). Once the machine is "divested of its function, abstracted from any practical context, [it] takes on a strictly subjective status" (8). This subjective status is the completed possession, which means "an object can either be utilized, or it can be possessed" (8).

In translating this theory of subjects and objects to characters it is helpful to think of how naturally fiction, often assumed to be a "representation of life", plays a role in our attempts to mediate our world (Mitchell, "Representation" 11). A possessive relationship is characterised by one subject's belief that their projection of the other - a fiction - "see[s] the truth" (Byatt, The Game 279). Rather than "refrain[ing] from trying to comprehend" others, the possessive subject approaches their object as totally knowable (Hegel 58, original italics). The possessor is interested in performing an imaginative abstraction on another person. To do 
so, the possessor works to reduce the other to their projected version of the person as a way to displace the other's persona: to reduce them to an object. If the relationship becomes dominated by attempted possession then two subjects do not meet on mutual terms, they are in a relationship of ownership.

This thesis begins with two chapters on The Collector and The Game, which I read as simpler, creative preludes to the authors' more complex later novels. The Collector delves into the psyche of an obsessive collector, Frederick Clegg, and his object of obsession, Miranda Grey. The novel reflects Baudrillard's theory through Clegg's desire for a romantic possession that leads to the sexual degradation of Miranda. A number of Byatt's works deal with possession, but the similarity in how The Collector and The Game show possession through a central subject-object relationship is particularly striking. ${ }^{1}$ Crucially, both novels portray the success of the possessor. In The Game two sisters, one a possessor (Julia Corbett) and one an object (Cassandra Corbett), clash over creative appropriation and possession. Julia is ultimately successful in her task by creating a new Cassandra in a fictional novel, causing the breakdown of the real Cassandra who was already only clinging to the threads of reality.

The obvious pairing in the thesis is TFLW and Possession because Possession was written partly in response to $T F L W{ }^{2}$ We can track the genesis of possession from two primary characters in claustrophobic, possessive relationships to the many conflicting attempts to establish subject-object relations by possessive characters in TFLW and Possession. In these two novels possession becomes a means to highlight the individual experience of a character, not an abstractive operation to be achieved.

The TFLW is a novel about power sought or obtained through possession, and freedom when one is neither possessed nor a possesor. The focal character, Charles Smithson, approaches his relationships with the view to possess his partners, particularly across class and gender lines. In my analysis I look at Charles's approach to Ernestina Freeman, Sam Farrow, and Sarah Woodruff. Sarah is a woman capable of recognising and navigating this kind of behaviour, and unlike Ernestina, Sarah resists Charles. In fact, she does so with all of the possessive visions that the inhabitants of Lyme Regis express of her. Sarah knowingly inhabits their visions of her, and in doing so is able to actively evade their reductions. In my

\footnotetext{
${ }^{1}$ See The Shadow of the Sun, Angels and Insects, The Biographer's Tale, and the short stories "Art Work" and "The July Ghost".

${ }^{2}$ In an interview with Nicolas Tredell Byatt discusses the "illicit sexuality" and "multiple, variant narratives" in TFLW (24). She further explains in On Histories and Stories that it was Fowles's remark that "the nineteenthcentury narrator was assuming the omniscience of a god" that inspired her to assert the opposite in Possession (56).
} 
final chapter I examine the secondary characters in Possession: Mortimer Cropper, Beatrice Nest, Ellen Ash, James Blackadder, Leonora Stern, Val, and Blanche Glover. In the novel, the scholars and their objects exist in different time periods, which creates a temporal distance. This means their attempts at possession take a different form to those in the other novels. They only have the literature that is left behind to try to enact their intellectual and creative possessions. Possession is a compelling novel to conclude the thesis with because the possessive order is reversed or is depicted as a mutual exchange. When Barry Olshen makes the interesting, although ultimately unconvincing, claim that Clegg "is fundamentally not responsible for his actions ... [, because t] he possessor is himself possessed; he is as much the victim as the victimizer", it is more suited to the scholars' experiences in Possession (22). The novel highlights the oppression the scholars experience as a result of their possessive desires for objects that cannot be physically accessed, and of their possession by those objects.

Possession is generally overlooked as a fundamental theme and critical path to reading the characters in these novels. However, it would have been a remarkable oversight had the theme of possession not been a prominent point in some of the previous Byatt and Fowles scholarship. If collecting is a symptom of the desire to possess, then the collector Frederick Clegg is the most straightforward character through which to review possession. Frederick Holmes recalls that the "destructive urge, appropriately called 'collectorconsciousness' by Palmer, is the desire for a proprietary relationship to the truth. ${ }^{3}$ It is the wish to possess, to control, to understand totally" (Holmes, "Paradox of Omniscience" 194). Holmes summarises the common critical approach to Clegg: "[b]y seeking absolute knowledge and control, one kills whatever life made the object under scrutiny desirable in the first place ... Clegg literally kills Miranda in an attempt to possess her" (194). Roland Binns argues that “[e]ach of Fowles's three male protagonists [Frederick Clegg, Nicholas Urfe, and Charles Smithson] recognises the consumer-attraction of the mysterious female who enchants him, and each seeks sexual possession of the object of his desire" (26, original italics). Olshen thinks of Sarah Woodruff as a "composite figure in the Fowles corpus, part Magus and part Collector" (87). Rosemary Laughlin also engages with the theme of possession in her analysis of power in the novels of John Fowles. She argues that Sarah Woodruff "lives to practice power . . . to possess another for the sake of possession" (85). Additionally, Laughlin says that "like Fred Clegg, [Sarah] is obsessed by possession, but unlike him, once the

\footnotetext{
${ }^{3}$ Fowles's second published novel, The Magus, features the Prospero-figure Maurice Conchis playing a "godgame" with the protagonist Nicholas Urfe (627).
} 
desired object is obtained she no longer wants it" (86). My opinion of Sarah differs, and there is not much within the novel that actually supports the claim that Sarah is obsessed by possession. She could be read as having sexually possessed Charles, but through her reinventions, and taking ownership of her own future, she appears not to be a possessor at all. Linda Hutcheon, the scholar who coined the term historiographic metafiction, which has been consistently applied to TFLW and Possession, recognises Charles's "need to reject the notion of possession as the purpose of life", but notes a contradiction in that "he wants to possess Sarah sexually" (295).

The Game has not usually been thought of as a novel primarily about possession. The two main characters are usually read as "split facets of the creative writer's imagination" (Todd 11). This counters reading Julia as driven by possession because it implies that their final fusion at Cassandra's death restores them as one whole being. The title of Possession notifies its readers to one of its key themes. In History and Cultural Memory in NeoVictorian Fiction, Kate Mitchell offers a strong analysis of the forms of possession in the novel, particularly the ideas of "self-possession" (10), and "mutual possession . . . between man and woman" (106), "between the text and an ideal reader" (116), and between the past and present (94). Louisa Hadley reiterates this last focus when she says "[r]eading does not always have such positive effects ... there are readings that seek to possess the past and in doing so deny it an afterlife in the present" (123). However, what critical literature currently exists on Possession is almost always focussed on the mirrored romantic plots of the four leads: Maud Bailey and Roland Mitchell, and Christabel LaMotte and Randolph Henry Ash. Samantha J. Carroll deserves recognition for her contribution to scholarship with her argument on how "Possession dispossesses [the] lesbianism" between Blanche Glover and Christabel LaMotte (362).

TFLW and Possession were both pioneering literary works. Fowles is credited, along with Wide Sargasso Sea by Jean Rhys, with the inception of the neo-Victorian genre through his "postmodernist experiment with the Victorians" (Hadley 2). Byatt's novel is considered a key text during the "crucial nodal point" that was the "surge in neo-Victorian fictions ... between the late 1980s and in the early 2000s" (Hadley 2). Beyond genre, the novels are thought to be exemplary of the postmodern literary movement in British fiction. James Acheson uses postmodern to mean "novels [that] present the world as a place that is endlessly complex and uncertain, often mirroring it by way of their self-conscious arbitrariness and constructedness" (399). TFLW is famous as a novel of "postmodern complexity" (Acheson 399). Possession is thought of as a "[q]uintessential contemporary novel” (Wells, "A.S. 
Byatt's Possession" 538). Due to these novels being considered postmodern exemplars, with Byatt and Fowles drawing from a wealth of influences, past analyses have applied many frameworks to their work. ${ }^{4}$ Their biographies, interviews, and nonfictional writing particularly appear to influence contentious critical trends. I do not subscribe to a strictly feminist approach, but feminism is on the periphery of discussions of possession as this is a theme that often characterises power dynamics between men and women. Therefore, it is relevant to establish how feminists have treated Fowles.

Fowles deserves some respect not only for his self-aware desire to be a feminist - "I hope I am a feminist in most ordinary terms" (Vipond) - but for highlighting the social constraints women face through his literature. He has also been reluctant to qualify himself as a feminist: "I am certainly not a feminist in the militant sense" (Baker). The initial claim was enough to spawn feminist attacks. None have defended Fowles against the likes of Bruce Woodcock's feminist attack with quite the same vivaciousness as William Palmer. It is worth quoting one of these defences in full:

$[\mathrm{P}]$ utting him on trial for focusing on the existential possibilities of heterosexual love rather than upon radical feminist[,] . . . Woodcock patronizes Fowles in sometimes comic ways: 'No doubt sincere in themselves,' Woodcock (who, remember, is a male feminist critic) writes, 'his views of feminism are necessarily suspect and overtly contradictory by virtue of the very fact that they come from a male position'. (“John Fowles and the Crickets” 9)

Michele Buchberger's feminist reading reviews Fowles's almost interchangeable use of feminine and feminist that surfaced in an interview with Susana Onega. Buchberger suggests "he elevates what he deems uniquely feminine qualities" in his literature (133). This is it necessarily useful to reading his fiction. I would certainly not shield Fowles from feminist critique, but if we are to undertake that task we must consider the context in which he is writing. His first publication came just after " $[\mathrm{t}]$ he feminism of the fifties [which] seemed to be more concerned with the integration and foregrounding of femininity in a masculine world” (Caine 223). During this time “"[f]eminism” was not discussed as

\footnotetext{
${ }^{4}$ Fowles's academic acme was the 1970s and 1980s when all of the book-length studies of his work were published, including those by William J. Palmer, Peter Wolfe, Barry Olshen, Robert Huffaker, Peter Conradi, Simon Loveday, and Carol Barnum. By the 1990s, Fowles's popularity had somewhat declined (his final novel was published in 1985). Byatt came into academic favour with the success of Possession, and has sustained interest into the 2010s. Important book-length studies include those by Kathleen Coyne Kelly, Richard Todd, Christien Franken, Jane Campbell, and Alexa Alfer and Amy J. Edward de Campos.
} 
something separate to "the feminine"" (Caine 237). Interestingly, Byatt has made comments on literary feminism, which she sees as having negatively impacted women's writing (“episode 102"). Byatt argues that "there has started being a thing like the women's novel of my childhood again ... when we got feminism, women come much more consciously to write about women, and the men became very flamboyant" (“episode 102"). The Game negatively depicts a parasitic women's writer, and Possession satirises the strident feminist Leonora Stern, but Byatt has remained largely exempt from the kinds of attacks Fowles has received.

Partly through their awareness of literary scholarship, Byatt and Fowles write novels that generously enhance the possibilities for interpretation. However, we have reached a point where it is time to re-examine how to approach these novels. I argue that the pathway to this is by closely analysing a small selection of the authors' novels, and returning to what is at the core of the relationships they portray. In these novels characters persistently develop possessive, rather than reciprocal, relationships with characters who they have deemed to be the object. By first utilising Baudrillard, "whose central concern . . . is the intimate relationship between 'possession' and the arc of human consciousness", we can track the different forms of possession that dictate the character dynamics in the four novels (Wendorf 12). By looking at two authors that have potent thematic similarities it better illuminates a concern shared by many people: these authors are, under the guise of influences and critical possibilities, observing the nature of relationships between human beings. 


\section{Chapter One: The Collector}

In the 1985 Modern Fiction Studies special issue about John Fowles, William J. Palmer claims: "The Collector has been so oft-analyzed that . . . [critics] seem hard-pressed to say anything new about it" (“John Fowles and the Crickets” 11). Responding to Palmer, Perry Nodelman thinks the reason for the "stifled debate" is the uncomfortable moral consideration that Miranda is bettered through her captivity (332). Here he channels a persistent argument, facilitated by Fowles's own assertion, that the novel is a "parable ... [of] the Few and the Many" (Aubrey 90). ${ }^{5}$ Variations on moralising readings such as this pervade the critical material, but some common frameworks include the analysis of gender, class, intertextuality, existentialism, and collecting. That the novel continues to fascinate suggests that The Collector has never ceased to haunt its readers, despite the seeming struggle over how to approach the "hideous novella" (Williams). ${ }^{6}$

The Collector juxtaposes Frederick Clegg, a self-educated, working-class clerk, with the young, middle-class art-student Miranda Grey, whom Clegg captures and imprisons. After winning a substantial sum of money at the pools, Clegg pays for an extended trip to Australia for his aunt and cousin (his only family), leaving him alone with his new fortune. He purchases a secluded home not far from London, and outfits a cellar in which to keep Miranda. The narrative is cyclical in nature, and presented in contrasting forms. The novel begins in the past tense from Clegg's first-person perspective. The second section consists of Miranda's chronological diary entries that revisit previously described events from her perspective. However, Miranda's text "is as firmly isolated as the dungeon in which she is kept" (Wendorf 21) because, along with her physical imprisonment, Clegg narratively "enclos[es] or symbolically imprison[s]" her when his perspective completes the narrative discourse after her death (Lynch 227).

Baudrillard's theory is a useful framework through which to review the possessive process portrayed in The Collector. Robert Wendorf similarly claims Baudrillard offers a "rich conceptual framework" for The Collector, stating that the novel could be considered "a psychological gloss on” Baudrillard's “jealousy system” (15). But Wendorf's suggestion is

\footnotetext{
${ }^{5}$ In the preface to the 1968 edition of The Aristos, Fowles mentions his interest in the "struggle between the Few and the Many, between 'Them' and 'Us"'. He claims his "purpose in The Collector was to attempt to analyse, through a parable, some of the results of this confrontation".

"In 2016, the "chilling classic" (Mountford) was adapted for the stage. In 2017, Saul Levmore's chapter "Kidnap, Credibility, and The Collector" was published; here he examines the legality of Frederick Clegg's and Miranda Grey's actions. Reviewing the feminist claims of the 2017 live-adaptation of Beauty and the Beast, Zoe Williams comments that it was The Collector that returned to her during her viewing experience.
} 
never developed beyond a general summary of the novel. I argue that through Clegg's physical and narrative dominance, the relationship is predicated on a process of possession based on unreliability, "the use of fantasy, . . . the characters' subjectivity, and the problem of authority and manipulation" (Salami 46). I distinguish three distinct phases in the way Clegg views Miranda: meditation (fantasising and stalking), capture and imprisonment, and transformation (sexual exploitation). If collecting is "anti-life, [and] anti-art", then in many ways the novel is a depraved Künstlerroman (Fowles, "Collector" 123). As Clegg moves from being a passive collector to an active creator, destroying and possessing Miranda, he achieves his creative masterpiece: a dead Miranda and the dehumanised and deconstructed pornographic images of her for his collection. My focus in this chapter is on the possessive process within the narrative, as we see it develop through the perspective of Clegg.

\section{Meditation}

Clegg's possessive desires begin in childhood. After his father was killed in a car accident while driving drunk, his mother abandoned him to Aunt Annie, Uncle Dick, and their crippled daughter, Mabel. While Uncle Dick was alive, Clegg found comfort spending time with him because, unlike Aunt Annie and Mabel who "despise . . . [his] butterflies", Uncle Dick encouraged his collecting (11). Clegg associates collecting with a positive relationship, admiration, and control, but it has been argued that "childhood collecting is [usually] displaced by an adolescent transference from desire for inanimate things to those which are animate, social and spiritual leading to friends and society" (Kline and France qtd. in Olmstead 288). Clegg is "alone all the time", does not have "any real friends" (23), and cannot sexually perform when he is with a woman (14). Since there is no transfer from the state of childhood desire for the inanimate to more developed forms of interaction, he never learns to see people in non-reductive ways. Reading Aunt Annie and Mabel through Clegg's perspective is the first indication of this. Aunt Annie and Mabel are predominantly described by Clegg in terms of what they suppress in him: his collecting, class progression, and sexual maturity, supposedly all things Miranda could elevate. This conceptualisation of Aunt Annie and Mabel is the first example of how Clegg characterizes others in terms of his own insecurities.

Fictionalising the 'other' (the object) is key to commencing any possessive process. In doing so, the possessor begins, in their mind, to conceptualise the other. Due to the overt comparisons of Miranda to butterflies, nearly all critics refer to her as a butterfly specimen at 
least once. Furthermore, scholars and readers consistently recognise her reduction "to the status of an object" (Olshen 17). To Clegg, Miranda and butterflies are analogues. Prior to her capture, Clegg records her movements through his "entomological observations diary" (10), stalking her around London like a "rare species" of butterfly (16), marking her only with an "X" (9). His descriptions of her are fragmentary, enforcing the reductive nature of this objectification. He is enamoured by her "pale blonde hair" (10) that is "silky, like Burnet cocoons" (9), which he often wants to "stroke" and "feel" (61). Clegg is physically drawn to Miranda when her hair either hangs in "a special curve . . like the shape of a swallowtail" (64), or is in "two pigtails" (73). The pinnacle of a butterfly's beauty is its wings and Miranda's hair when worn up evokes, for Clegg, the movement and symmetry of wings. There is an erotic charge to Clegg's gaze, and he views Miranda's hair as her defining feature because it mirrors the physical beauty of a butterfly. ${ }^{7}$

Butterflies have a historically symbolic meaning. The Greek figure Psyche was "represented in works of art as having butterfly wings, or as a butterfly", and the word psyche means "[t]he mind, soul, or spirit, as distinguished from the body" ("psyche"). Due to this, the choice of butterflies as the object of collection heightens our understanding of collecting in the novel as integral to Clegg's "self formation and maintenance" (Mead qtd in. Olmstead 296). The butterfly collection is not separate from Clegg, the butterflies are a part of his psyche and make up his "personal microcosm" (Baudrillard 8). Furthermore, in Clegg's imaginary life not only will Miranda be a butterfly in the collection, but she is also required to love, admire, draw and colour (10) her "fellow-victims", to fully integrate into Clegg's microcosm (127).

One of the fictional archetypes that Clegg employs for Miranda is that of "the captive woman in [Jeanne-Marie Leprince] de Beaumont's tales and many others" who transforms the captor (Lynch 230). When Clegg designs an enclosed space with "drawers full of clothes" (118), "art books" (23), everything a "girl would need", into which he can introduce Miranda, he creates a cocoon for his possession (24). The reference of her hair to the colour of a cocoon expresses her capacity for rebirth; the caterpillar undergoes metamorphosis inside the cocoon to become the butterfly. Clegg paradoxically sees Miranda as the butterfly that is ready to be caught and kept in its case, but also as the cocoon or chrysalis to metamorphose

\footnotetext{
${ }^{7}$ Bavjola Shatro dissects the word 'butterfly' to suggest that it "directly evokes the expression 'flutter by"' (73), which to Clegg has "an immediate association between ... [the] experience of Eros and femininity and the fluttering nature of the butterflies" (73). This is an oversimplification. Miranda's hair is less about femininity than what it symbolises.
} 
him romantically and socially; she will act as his soul. Clegg's early meditations on Miranda also parallel the Pygmalion myth. Clegg sculpts 'Miranda' in his mind, imbuing her with his perfect qualities. They become "the popular host and hostess" of the "Bug Section" gatherings, and live "in a nice modern house, married, with kids" (19). Clegg's sculpture is supposed to come to life once she is in her place in his system and under his control. For his "domestic dream" to be actualised Clegg must remove Miranda from her life (Lynch 231). The cellar becomes a space to create his fantasy because he "wouldn't have a chance in London", her social realm (39).

Miranda is conscious of her status in Clegg's collection. On learning Clegg "collect[s] butterflies" she comments "[o]f course ... now you've collected me" (43). Miranda knows she is a "butterfly he has always wanted to catch" and recounts the opinion of G. P. (her middle aged art mentor) that "collectors were the worst animals of all . . . They're anti-life, anti-art, anti-everything" (123). Clegg is under the illusion that he would "do anything" for Miranda, including abandon his butterfly collecting (44). To this, Miranda curtly responds "[e]xcept let me fly away" (44). Although encapsulated in the personal microcosm and physically mirroring the butterflies in his mind, as Clegg's first human item she is not so easily acclimatised to her new life as the object.

\section{Capture and Imprisonment}

A teacher once told Clegg that "Power corrupts... And Money is Power" (24). Indeed, money is what enables Clegg to implement his fantasy of the capture and imprisonment of Miranda. After "ten days" of stalking Miranda in London, the opportunity arises to capture her, "as it sometimes does with butterflies" (26). Clegg is excited the first night his "guest" stays, and ruminates on his "worthy [love] of her" (30-1). When Miranda is confined to the cellar, the extent of Clegg's fictional projection can be realised. Both characters engage with "wild swings of identity, so Clegg can go from Caliban to Prince Charming, and Miranda from princess to prostitute" (Lynch 238). Richard Lynch establishes that "assigning those identities is to confirm their own imagined selves . . Such use of intertextual identities and narratives makes intersubjective or shared thinking impossible" (238).

Clegg initially feels that the discrepancy between their social classes is the impasse in their relationship. According to John Su "characters [in the novel] are drawn to collecting in response to frustration with their class positions and social identities more generally" (684). 
Clegg first attempts to eradicate the class division between himself and Miranda by mimicking what he thinks are middle-class values and a middle-class environment. Such behaviour is elucidated by Pierre Bourdieu who articulates a sociology of aesthetic taste in Distinction: A Social Critique of the Judgement of Taste. Bourdieu claims certain activities and tastes are deemed "highbrow", such as "owning a record-player[,] . . knowledge of painting-features", and enjoyment of French culture (14). Bourdieu's work confirms that highbrow activities can be "strongly linked to educational capital, [and] set the various classes and class fractions in a clear hierarchy" (14). Miranda fits within the upper levels of Bourdieu's hierarchy. She uses a "French-scent" (81), and demands "a radio or a recordplayer" (47). Bourdieu notes that "of all the objects offered for consumers' choice, there are none more classifying than legitimate works of art" (16). When Clegg first designs the cellar for Miranda's stay he lays a "nice bright orange carpet (cheerful) ... [with] a bed and a chest of drawers. Table, armchair, etcetera ... [and] all the etceteras" (23). The etceteras, such as "art books and ... novels", are Clegg's replication of highbrow aesthetic taste (23). However, he does not "risk pictures" in the cellar in case Miranda has "advanced taste" (23). Clegg reaches the limits of this replication once he requires a human component, who he expects to comply, to bring his "world within a world" to life (Pearce 131). His confrontation with the reality of another human being comes to the fore in an altercation over their incompatible tastes; Miranda is angered over "the wrong colour carpet" and "horrible!" pictures in his living room (52). Clegg begins to learn that he cannot attain a middle-class state only through these static items and the kidnap of a middle-class girl.

The particular references to art and photography in the novel highlight the class frustrations of Clegg. Clegg and Miranda both engage a teacher-student dynamic that only serves to emphasise Clegg's delusion of reciprocity, and Miranda's delusion of autonomous power despite her confinement. During her first days in the cellar Miranda notices "the collection of books on art" (118). This collection of books, other than signifying that she was familiar to her captor, establishes Clegg's aspiration that Miranda will transfer her artistic knowledge to him. However, while Clegg can only collect books, Miranda can understand them. Bourdieu distinguishes "three zones of taste which roughly correspond to educational levels and social classes: (1) Legitimate taste ... (2) 'Middle-brow' taste . . . (3) [and], 'popular' taste" (16). Clegg could be placed in the "popular" taste group because of his "systematic reduction of the things of art to the things of life" (Bourdieu 5). More simply, it is the utility of the art that is attractive because the images reflect the "reality of their function" (Bourdieu 200). Over the course of the novel, Miranda uses her knowledge of art to 
express her social incompatibility with Clegg. She questions his knowledge on art, while ventriloquizing G.P.'s opinion that photography is “not living art. It's not a limb of your body" (158). Furthermore, she thinks Clegg would not "imprison an innocent person" if he could understand art (43). Clegg's lack of artistic knowledge is apparent in an interaction between himself and Miranda involving 10 drawings of a bowl of fruit. Miranda uses the drawings to test Clegg, pinning them to the wall and asking him to choose the best.

Unsurprisingly, Clegg chooses incorrectly and reports: “" [t] hat's the worst,' she said ... I had three guesses, they were all wrong. The one that was so good only looked half-finished to me, you could hardly tell what the fruit were and it was all lop-sided" (60). Miranda already knows what Clegg's answer will be because "of course he picked all those that looked most like the wretched bowl of fruit" (132). The images Clegg prefers are not only the most realistic, but they are also the most static, whereas Miranda prefers to be "on the threshold of saying something about the fruit" (60).

Regardless of his desires, Clegg "cannot subjugate Miranda's independent nature or the free play of her imagination within the walls of his own static version of reality" (Pifer 45). Once we access Miranda's diaries we see the extent of the imaginative inner life that she sustains. Ellen Pifer's note that Miranda is not a "malleable young 'specimen"” who refuses "to conform to Clegg's fantasies" is not entirely true (5). Miranda does indeed turn down his marriage proposal, but she also misreads his desires. Miranda thinks of their relationship through literary parallels, Shakespeare's The Tempest and Jane Austen's Emma in particular. She believes Clegg should have been called "Caliban" when he claims that his name is Ferdinand (61), and defines herself as Emma Woodhouse (157). Furthermore, Miranda employs a fairy tale, as one would to appeal to children, about a "monster who captured a princess and kept her in a dungeon in his castle" (187). On hearing this tale Clegg can only respond that he loves her (187). Although Clegg exerts control over Miranda when he captures her, during her time in the cellar she does not easily submit herself to his imagined life. Neither holds power in the way they think: Miranda retains some sense of her own autonomy by placing herself in the role of teacher, and Clegg allows this dynamic to continue to deny reality and his so far failed possession.

\section{Transformation}

Michelle Buchberger questions how the novel "elevates . . intuition over logic, adaptability over the need to adhere to tradition or to encourage stasis (associated with an 
obsession to fix and pin meaning ... and the urge to create as opposed to the urge to collect" (133). In the novel, art relates to intuition and adaptability, while photography is associated with logic and stasis. Even when Miranda sees Clegg as "an object, not a person”, it is Clegg who must abstract and annihilate Miranda to become the perfect collector (58).

Mahmoud Salami claims that in the 1950s and 1960s "the dominant ideology revolved around the equation of sexuality as a correct social order" (97, original italics). Early in the novel, when Clegg describes how he hired a prostitute but was unable to sexually engage with her, he blames this on how "she was old and she was horrible . . both the filthy way she behaved and in looks" (14). Clegg is unable to engage with a living woman, and only thinks of the prostitute in dehumanised terms: she was "worn, common. Like a specimen you'd turn away from, out collecting" (14-5). Clegg has difficulty with any living woman who engages him sexually, but he is able to fulfil his sexual appetite with pornographic images. These images began with "books of stark women" that he would have to hide from Aunt Annie (5). His voyeuristic drive leads to pornography collecting. Out photographing butterflies he says "you'd be surprised the things couples get up to in places you think they would know better than to do it in, so I had too" (15).

In contrast, Clegg feels Miranda is "very refined-not like the other ones, even the pretty ones" (9). Furthermore, Clegg thinks he has a higher moral compass "than most nowadays" who are "immoral" because he has "never been like that" (13) and has "always had higher aspirations" (15). The novel unfolds to uncover his faux-bourgeois morality, just as falsified as the objects in his home. Clegg struggles to come to terms with, and to even acknowledge, his sexual urges. He is sexually repressed, and begins to enact his sexual nature through his photography in a secretive manner. He misinterprets Miranda as an un-sexualised woman, and tries to move into his idea of her 'social order'. Essentially, Clegg tries to play the role of a gentleman.

When Clegg initially asks Miranda to pose for photos it appears innocent: "I'd like to take some pictures of you. 'Why?' You're what they call photogenic" (55). The photographs are similar to the initial recordings in his observations diary. They are "[j] ust ordinary, of her sitting reading" (58). The closer Clegg's actions move Miranda towards a pornographic photo shoot, the closer Miranda descends towards death. Once Clegg treats her as a part of the pornography collection she will have attained an abstracted object-status.

After first showing Miranda his butterflies, he mentions that he does "photography" (55). He then lays some of his prints on a table. The photographs are "of the woods behind the house, and some of the sea coming over the wall at Seaford" (55). This interaction, like 
with the drawings of the fruit, directly contrasts their views on art. For Miranda "they're dead ... [as are] all photos. When you draw something it lives and when you photograph it it dies.” (55). To Clegg “it's like a record” (55). Here, Miranda unwittingly reveals her own fate; for Clegg to possess he must kill.

The possessive shift in the novel occurs when Miranda attempts to seduce Clegg to gain her freedom. This corrupts Clegg's desexualised vision of her asexual purity, and the encounter is exemplary of the misinterpretations that occur between Clegg and Miranda. Miranda knows that Clegg hopes "the dream Miranda will appear", but thinks he wants her to put her "arms around him and kiss him. Praise him, pat him, stroke him" (236). After a night's reflection she decides to give him a "tremendous shock" that will force him to release her (237). When Miranda stands before Clegg naked he "feel[s] sick and [begins] trembling" (99), and keeps “thinking, stop it, stop it, it's wrong” (99). Miranda's sexual initiative corrupts his "fairy tale" where she had once been "cast in the role of princesse lointaine, the distant princess" (Lynch 234). Before she could not be touched, and offering herself to Clegg means that, for Clegg, she "killed all the romance, she had made herself like any other woman"(103). Clegg treated his fantasy as though Miranda would occupy a space in the system as a living, but "useful object" as a butterfly (Engels 69). After her failed seduction he is confronted by the realisation that he has not possessed her as he had first hoped. The novel then progresses to the rape and death of Miranda as she is objectified by Clegg and abstracted of individuality. The butterflies, Miranda, and pornography eventually become intertwined as one collection.

After the incident, Clegg wants to take a "portrait" of Miranda (127). While reflecting on this request, Miranda ruminates on the butterflies: "then there were his butterflies, which I suppose were rather beautiful. Yes, rather beautifully arranged, with their poor little wings stretched out all at the same angle. And I felt for them, poor dead butterflies, my fellowvictims" (127). Clegg fastidiously arranges his butterflies. After he has killed them he is able to control their positioning, visually fixing them as per his will. Miranda will come to be arranged according to Clegg's desires too. The photographs are gradually dictated and then finally physically controlled by Clegg. At the beginning, the photo sessions have the appearance of a consensual dynamic: "yesterday evening he wanted to take a photograph of me. I let him take several” (129). Miranda is still under an illusion that she has some control because she can decide when, and how frequently, the photographs are taken (181). However, Clegg's demands escalate: "I want to take pictures of you like you were the other evening ... And you've got to look as if you enjoyed posing ... You've got to pose the way I tell you" 
(106). Miranda thinks the photographs will be "obscene" so that if she escapes she "shan't dare tell the police" about Clegg (106). In contrast, Clegg sees this as his artistic awakening, they will be "Art-photographs" (106).

There are two instances where Clegg takes explicit photographs of Miranda. The first is after he chloroforms her because she has attacked him. He leaves on "certain articles ... [including her] brassieres" (87). He describes her as a "real picture lying there" and quickly retrieves his camera to take photographs of her (87). He remarks that they "came out very nice. Not artistic, just interesting” (87). This shows how his attitude towards Miranda is changing. Clegg comes to realise that photographs of Miranda are all he needs in order to possess her. With a photograph he is under no pressure: “they didn't talk back at me. That was what she never knew" (103).

In a moment of anger, Clegg ties Miranda to the bed and gags her before he takes "her garments off" (110). Although she initially fights, he overpowers her and she submits to his demands. Clegg reports: "I got my pictures. I took her till I had no more bulbs left" (110). This final line, evocative of ejaculation, expresses the violence of this sexual encounter. His later comments are of particular relevance because he thinks "the best ones were with her face cut off" and "when she stood in her high heels, from the back" (110). I argue that the result of this rape is depersonalisation. In response to not submitting to his will over the course of her imprisonment, Clegg's punishment is to take away Miranda's agency and to remove her individuality: her face. Aside from the violence, the violation is that she is no more than a decapitated body in an image. It is through these images and her subsequent death that Clegg is able to finally amalgamate Miranda into his collection. When Mirand later becomes ill she no longer has the butterfly's beauty that remains fixed in time, she is no longer the angelic virginal image, but has "nasty yellow pimples one corner of her lips", and her hair sticks to her sweating face (263). Clegg achieves his collected masterpiece through Miranda's death. She is no longer a living, dynamic person, but a possessed pornographic image.

After her death, Clegg "comb[s] out her hair", "cut[s] a lock", and tries "to arrange her face so it had a smile" (274). To Clegg it is when her body no longer has any life that it looks "very peaceful" (274). In her last moments he removes her wings, and tries to arrange her in a way that still fits his fantasy image of Miranda. Following this, he plans to take a last look at his collection, and kill himself, sealing their story in Romeo and Juliet fashion. Before this, however, he discovers her diary, through which she had lived an alternative existence outside of the cellar in her memories, and so he chooses to continue collecting. Following his 
failure with Miranda he is forced to aim lower. Shatro says that "with Miranda's death, Clegg seems to be clearer about how to play and fulfil his distorted erotic desires through his future victims, who are no more to him than new samples to his collection of dead butterflies" (66). For Clegg, Miranda's death has no significant meaning, the cycle of the collector will still continue. "[T]he great dead thing in" Clegg is that "he's a collector" (Fowles 61) and so "[h]e will keep on collecting 'death"” (Jodar 52).

Whether Clegg recognises his own social station, or develops an inflated sense of self is unclear, but when he discovers Marian he reassesses his approach. She "isn't as pretty as Miranda" (282), and "[h]er name ... [is] a transposition of "Miranda," diminished, with one letter missing" (Wendorf 22). Clegg decides that he had initially "aimed[] too high" with Miranda: "I ought to have seen that I could never get what I wanted from someone like Miranda ... I ought to have got someone who would respect me more. Someone ordinary I could teach" (282). Her physical similarity to Miranda is expressed by Clegg's note that Miranda's clothes "would fit" (283). Clegg shows a change in attitude from when he stalked and captured Miranda, to when he starts to stalk Marian. Rather than building an image of her in his mind, he thinks of her in an entirely specimen-like manner. He will take her "for the interest of the thing and to compare them and also the other thing, which as I say I would like to go into in more detail" (282). The 'other thing' likely refers to his pornographic photos. At the start of the text Clegg says "there were moths too. I thought I might take them up" (16). Where Miranda was a butterfly, Marian is a moth. Marian will not have the same space in the collection as Miranda originally did. She is already void of personal significance, being referred to as a 'thing'. Collecting is cyclical and thus never complete. Even when the original purpose of possession has been achieved, the impulse leads the collector to continue their obsession through new acquisitions. 


\section{Chapter Two: The Game}

A. S. Byatt's The Game centres on two estranged sisters, Julia and Cassandra Corbett. The younger sister, Julia, is a writer concerned with "domestic claustrophobia" (53). For her novels she draws on her home life: her marriage to Thor, a "paid administrator for a ... charitable organisation run by the Quakers", and her relationship with her teenage daughter Deborah (4). The elder sister, Cassandra, is an Oxford don who specialises in medieval literature. Cassandra lives in self-imposed seclusion, predominantly experiencing life through an imaginary inner world. She is a spinster-figure, a virginal woman not possessed by any male figure. The novel shifts in time and form, detailing their childhood and adult lives through prose, diaries, reviews, and letters.

Mariadele Boccardi argues that the modeling of Julia and Cassandra on "the Brontë sisters", although she does not specify which sisters, is intended to "complicate any attempt to draw a clean line between life and literature" (32). ${ }^{8}$ What Boccardi circumvents is reading the novel as a roman-à-clef about the infamously fraught relationship between Byatt and her younger sister, the novelist Margaret Drabble. The novel has been read as a narrative exemplar of their relationship. ${ }^{9}$ Boccardi articulates a credible concern that a biographical reading would be "too straightforward a transposition" that overlooks "many of the complexities of the novel" (32). Nonetheless, while my reading does not belabour the biographical dimension, it is pertinent to address how the Byatt sisters' relationship, and the novel's treatment of female creativity, influence the sparse but repetitive critical material. ${ }^{10}$

Jane Campbell quotes the introduction to The Shadow of the Sun when she discusses how The Game probes "the problem of female vision, female art and thought" (1). Related to this are the readings of Julia and Cassandra as "split facets of the creative writer's imagination" (Todd 11), and as "a creative feminine whole" (St. Clair 1). Pamela St. Clair argues that the "divided female imagination" symbolically suggested by Julia and Cassandra is "incomplete" by the end of the novel (iii). Similarly, Kathleen Coyne Kelly argues that

\footnotetext{
${ }^{8}$ There is also an echo of Vergil's The Aeneid when Anna unwittingly helps to build her sister Dido's suicide pyre.

${ }^{9}$ Joanne Creighton compares The Game with Drabble's The Waterfall. Katherine Ashenberg comments on the parallel in a short piece in Toronto Life, as does Daphne Merkin in the New York Times in a piece on Drabble.

${ }^{10}$ It is surprising that The Game, and Byatt's first novel The Shadow of the Sun, have been so critically neglected. Both novels establish in Byatt's oeuvre the theme of 'possession' as bound to female creativity. Anna Severell in The Shadow of the Sun struggles against "the all-consuming . . . force that is her [novelist] father", her mother, and male mentor (Alfer and Edwards 11).
} 
"the final meaning of The Game is left unresolved" (35). I suggest that it is the implied cyclical nature of Julia's possession that creates this feeling of incompleteness.

In her reading, Joanne Creighton justifies Julia's actions against Cassandra by arguing that the novel "demonstrate[s] that a certain amount of 'monstrous' appropriation of others is essential for the artist, including the female artist who has been taught such aggression is "unfeminine"” (23). Scholars appear reluctant to acknowledge the cruelty of Julia's possessions and, as a result, avoid interpreting the female artist as negatively destructive. This is likely a remnant of the feminist sisterhood, but I speculate that it is also because of the link between Julia and Drabble, Drabble being herself a popular writer. Although this is not a hypothesis I explore, I pose that it is worth ruminating on whether the dilution of Julia's actions in criticism is to avoid confronting the possessive nature of Julia's artistry.

My reading of The Game sympathises with the position of Cassandra's character. In doing this, I am responding partly to the scholars who insist on treating Julia and Cassandra as equally responsible by reading Julia as not driven by possession, and Cassandra's retreat as an unfair dismissal of her sister. ${ }^{11}$ To challenge current scholarship on The Game, I propose that we look critically on Julia's supposed "composite portrait", her "binary fusion" of herself and Cassandra (179). In my reading, the sisters do not undergo a fusion; I argue that Julia absorbs her sister, thus possessing her.

The Game "dissects the ways in which any form of representation inevitably distorts reality, but at the same time poses uncomfortable questions about the power of the imagination to create reality, thus reversing the intuitive order of primacy between the two" (Boccardi 39). When Julia is able to overtake Cassandra's reality through creative means the reversal can be described as a possessive one. Julia projects new realities, and then works to reduce others to this projection. To my knowledge, critics so far have not noticed the similarities between The Collector and The Game. The Collector embodies similar concerns as The Game, but on a different level. Clegg's actions are only physically corruptive. His imagination distorts, but he is never able to invade Miranda's psyche; one can own a 'butterfly' but not someone else's soul. The Game complicates portrayals of possession by intersecting forms of imaginative distortion between Julia and Cassandra. Julia is "obsessed with [her sister as] the 'other'" and attempts to possess her throughout their lives in a relationship that notably lacks reciprocity (Creighton 18). Julia is eventually able to achieve

\footnotetext{
${ }^{11}$ Richard Todd reads Cassandra as having "a dangerously vindictive streak" and that the "sisters come to possess each other" (10). Jane Campbell recapitulates this argument when she suggests that Cassandra's papers have power after her death (51). Creighton argues that Julia "merge[s] with Cassandra" (23).
} 
the same ends as Clegg - the destruction and possession of her object - but she does not, at least not directly, physically harm her sister. Julia destroys Cassandra's hold on reality by targeting, and supplanting her sister's reality with her fictional creation, Emily. She may not touch her directly, but she does drive her to suicide all the same.

\section{Childhood}

The novel takes its name from an elaborate imaginative "Game" between the two sisters (50). Julia was consumed by this game from ages "seven" till "seventeen" (51-2). They "worked entirely together, and the plots they created consisted largely of the machinations of organized military antagonism", before they moved on to "intrigue, misguided love, and eternal hatred" (51-2). The Game involved an "oilskin . . clay figures . . . little cards, which were written over with rules and forfeits" (51). With their developing literary knowledge, the Game "increas[ed] in length and complexity" (51). Their "armies . . . expanded beyond their original thirteen men ... when Cassandra had discovered Morris, Tennyson, the Morte d'Arthur", and "Queen Morgan, [and] Elaine of Astolat" (51-2). Yet, even though " $[\mathrm{b}]$ oth sisters were aware that the other's imagination was also vigorously working in private on what was discussed less hotly in public, over the map", Julia is unable to accept that her sister has a private world (52). In childhood1 Julia would read Cassandra's journals, and as a result, there were "passwords" to get into Cassandra's room, and things were kept in "locked drawers, and locked boxes" (50). As an adult, Julia feels that Cassandra unjustly criminalised Julia's craving for access to the forbidden (288). After reading Cassandra's journal, Julia would wake up "screaming and sweating" in the night (52). At this time Cassandra held power over Julia through her creative work because it sustained a deliberate distance between Julia and the real Cassandra. Even in adulthood when Julia reminisces on the Game she speaks of Cassandra's control in the present tense: "she conducts the Game" (97). Eventually, Cassandra ceases participation in their shared world to distance herself from the possessive force of her sister after Julia enacts a creative and then romantic "theft" (81). Julia's first published work was at the age of 16 when she won a short story competition with her piece "Vigil in the Forest" (81, original italics). By this time, Cassandra had gone to Oxford, and left behind in her "window-seat [were] several versions of the same story" (81), one of which she had submitted "for a school exercise" only to be told "you must learn to curb the more lurid flights of your imagination and write with more discipline to be really effective" (82). Julia "successfully submitted" a version of this story "to the 
competition" (82). It is implied that the story was a part of the Game and so Cassandra felt an accusation of "simple theft" did not suffice (82). Her conflicted feelings further stem from Julia's elevation of "her own lumpy version", which highlighted Cassandra's sense of inadequacy as an independently creative writer (82). Nevertheless, her "imagined world had been violated ... the exposure had rendered [her and] it lifeless" (82). Consequently, Cassandra became "unable to write" for months, and "punished Julia by silence" (82). Cassandra is able to halt the possessive process that could have begun with Julia's initial theft. Like Sarah in The French Lieutenant's Woman, Cassandra is aware of the power of silence to retain distance from objectification. At that time, this forced Julia into creative independence, but her next story was rejected, and she struggled to continue the Game alone (83).

The other rift in their relationship is caused by the herpetologist and collector Simon Moffit. Cassandra is the first sister to form a relationship with Simon. When she started at Oxford in 1943 Cassandra immersed herself in religion because it "seemed harder, more inevitable and more reliable than the Game" (83). After returning home for Christmas, she "invaded the study of her parents' friend [the Vicar] Edwin Merton" (83-4). At the time, Cassandra had been ready "to fall in love, or to undergo a religious upheaval" (84). She spoke with Merton of her "sense of meaninglessness", and he introduced her to Simon (84). Simon's anguish was caused by a hostile upbringing and his father's suicide, and Simon and Cassandra's relationship develops through their mutual need for spiritual comfort. Their courtship consisted of Cassandra accompanying Simon to meetings with the Vicar, where they shared ruminations on their concerns for "the historical truth of Christianity" (89). For Cassandra, these sessions developed into the feeling that "human[s] need to imagine", that there must be "more than facts to live by", and that "the death of Christ is imaginatively necessary" (89, original italics). In contrast, "Simon . . . abdicated the attempt to reconcile love and suffering" (89). Facts became his "only available truth" and the imagination "an instrument for scientific comparison" (89). Despite their differing opinions, the two find comfort in these debates. Simon is the only material collector in the novel. We learn that when he was younger he "kept snakes. In jars and tanks" (21), and when he returns from years in the Amazon he brings with him "bags of snakes" and "long crates and occupied cages" (180). An entry from Cassandra's journal in 1944 reveals her delight when he shows her his collection of snakes (85). She writes "I imagine he would not show them to most people ... [and he] says he has 'for some reason' always kept them a secret" (85). Simon's snakes are like Clegg's butterflies in that they symbolise both an extension of his self, and his 
personal microcosm. Cassandra is aware of the significance of Simon inviting her into this private sphere. Other than the Game it is the only other personal space that she has shared. His invitation and her willingness to proceed was a mutual meeting of two subjects who had traditionally distanced themselves from interactions with others.

During a university term when Cassandra was back at Oxford, Julia and Simon have an encounter at the post office while both are posting a letter to Cassandra (93). It was a meeting that Julia "had imagined ... many times" (94). This meeting, and the many that follow, are dominated by conversations about Cassandra. Julia gives the impression that Cassandra has confided in her about Simon when she says "I know an awful lot about you" (94). She fails to explain that "what she knew had been gleaned from Cassandra's diary" (94). Their conversation highlights the ways that Julia manipulates social interactions. She damages the trust between Simon and Cassandra through her selective sharing, and solicits sympathy when she tells Simon "she doesn't like me, that's what I'm trying to say. She never has, for as long as I can remember. She - she doesn't like sharing things. She won't want me - sharing her particular friends" (96, original italics). Many of Julia's words in the novel are italicised, and in this instance it emphasises a distance between the Julia she presents to Simon and the Julia who has consistently invaded Cassandra's privacy. Julia creates a character when she interacts with people, and with Simon she portrays herself as the disregarded sister who wishes to have a closer relationship with her older sibling. When Simon questions why Cassandra does not like her Julia puts the blame entirely on Cassandra. She claims that Cassandra is responsible for her lack of friends in school, and further elicits Simon's sympathy by saying she had "worship[ed] her", only to be ignored (96). Simon plays into Julia's desire that they both analyse Cassandra's behaviour. He begins to make assumptions about Cassandra, suggesting that she is jealous because Julia is "engage[d] with life" (97). In conversing with Julia, Simon is complicit in the reduction of Cassandra to an idea: "you never feel she's all there, do you? ... she just doesn't quite exist" (97). This form of objectification, in their minds, distances Cassandra from reality. In Cassandra's absence, Julia manages to annihilate Cassandra as Simon had known her. Julia asserts to Simon both her own identity as the wronged sister and the identity she has created for Cassandra.

After the relationship between Julia and Simon develops, Julia begins to worry about Cassandra's return because "her parents . . . so clearly and tactfully saw Simon as Julia's first boyfriend" (97). It is Julia that informs Cassandra that Simon has asked them both to tea. It is significant that Julia is the one to ask Cassandra. Cassandra had dreamt that "Simon's warm presence would vanish whilst her attention was elsewhere" (125). Here her dream is 
actualised, with Julia usurping Cassandra's place beside Simon. When she watches Julia laugh with Simon he becomes further distanced from her, as though she "had not known him" (111) and "Julia's touch had made Simon seem forever inaccessible" (116). When, as an adult, Julia still believes that "Cassandra had behaved abominably over the whole thing with Simon", it signifies her continuing lack of remorse (55). Julia cannot recognise the destruction of her own possessive desires or fathom why Cassandra would retreat into an inner world away from her, even after she has destroyed Cassandra's one human connection.

\section{Cassandra}

Cassandra fills her Oxford room with objects she deems "solid" to form a system of comfort and security (14). This behaviour is a defence against invasion. Unlike the cellar that imprisoned Miranda, Cassandra "cultivated her walled-garden skills" and creates a boundary between herself and the outside world, specifically Julia (16). Her books, "globes and maps" are importantly "acquired, not inherited", which characterises Cassandra's need for this room to be self-formed and not someone else's creation (14). Cassandra's self-contained life at Oxford is also a clear break from her childhood home life. She is a teacher and a scholar, has her own acquaintances and a new faith, Catholicism, all of which are beyond Julia's reach.

Mieke Bal argues that "[t]hings, called objects for a good reason, appear to be the most 'pure' form of objectivity (99). Cassandra thinks you "shall never know more of than that they are there" and because of this approaches people and objects in the same way in an attempt to never reveal herself to anyone, nor to have them revealed to her (86). At her father's deathbed she tries to "detach herself, not to think . . . she thought, she must not sum up in her mind her father, who was not dead, and might not be dying" (43). Her attempts not to think about a person beyond what is physically present are suggested to be futile as our imaginations are always at play during interactions. Furthermore, Christien Franken argues that "Cassandra's fragile ego-boundaries contribute to an increasing imbalance of real and imaginary worlds. These boundaries are, in turn, undermined by other people's visions of her $\ldots$ as a result Cassandra withdraws further and further from anything that resembles a 'world', be it real or imaginary" (72). Before this fatal process is complete, Cassandra relies on the solidity of objects to situate herself in the physical world. When she looks "from object to object" in her room she is "relieved to see nothing but what was solidly there" (14). She takes time to touch the objects, to rearrange and align "with precision", so as to anchor her to this reality (127). Cassandra must be able to see and touch, to exist physically. 
The existence of Cassandra's journal permeates the novel. In the novel's present it contains monotonous descriptions of her daily life. The journal is used by Cassandra to distinguish "between what was real and what was imagined" (22). Like the objects, the journal is a means to document and hold on to her desire for an objective existence by grounding her life in surface descriptions. She tries to see the world in facts, as did Simon as a teenager. However, Cassandra feels "occasionally distressed by the extent to which the events and solid objects around her were only remarkable in so far as she 'collected' them for the journal" (22). The journal functions as a microcosm created via imaginative collecting. Within this journal she creates herself and collects for her alternative reality. When she is met by Thor at the train station she "defensively repossessed herself of her brief-case, which contained her journal", after he initially carries it for her (27-8). The novel frequently hints at Cassandra's gradual deterioration. She believes any objects in her possession, particularly her journal, are liable to infiltration. Thus, when Thor carries the briefcase he carries with him 'Cassandra'. Cassandra, paradoxically, seems to find comfort in both the solidity of objects, and the prospect of hidden meanings beneath them. If the truth of her lies beneath the simple writing then she is more than "an object of Julia's speculation, [and] Julia's tale-telling”, because she cannot be reduced only to those images (107). Even though Cassandra tries to disengage from visions of other people and of herself, she dramatically fails when Simon reappears on a television program and she starts to incorporate a fantasy version of him into her journal.

Simon and Julia eventually begin to overtake Cassandra's separate life. The first indication of this shift is Cassandra's recognition of Deborah's, Julia's daughter, physical similarity. It is as though Cassandra is meeting her doppelgänger. Her hair, like Cassandra's, is "a springing mass of gingery, wiry curls ... Deborah's hair and freckled nose ... [are] uncanny" (37). Deborah "intensifies the sense of sisterly interpenetration", and the physical similarity means, to some extent, that Julia has produced her own Cassandra (Creighton 23). Furthermore, Julia violates Deborah's privacy in the same way she did Cassandra's. Julia enters Deborah's room despite the "Keep Out. At Work. This Means You" sign, and "shuffles through her papers and reads her diary (150). Deborah confides in Cassandra about her mother's invasive treatment. Julia steals her daughter's words, writing their interactions into her literature so that Deborah's thoughts are no longer her own (79). Interestingly, Deborah appears as a character that Cassandra could have formed a relationship with because of their shared experience. However, the novel aligns more with the doppelgänger myth, whereby meeting your doppelgänger symbolises death. In their conversation, Cassandra 
remarks to Deborah, “[w]e all diminish each other. We all impinge on each other." (78). Deborah's existence as the offspring of Julia diminishes Cassandra because it represents the possibility of Julia's possession of her. If she can biologically reproduce Cassandra's physicality, then she can go on to finally possess her.

When Cassandra agrees to host Julia at Oxford, Julia's quest for "a real object" for her book begins in earnest (127). Cassandra allows Julia into the workings of her daily life. She shows her around Oxford, brings her to the dining halls, her room, and throws a dinner party for Julia with her acquaintances. When in Cassandra's room “Julia wandered up and down, restlessly, touching everything, fingering figures over the hearth, rearranging pens on the desk, reading bits of essays, spinning globes with a finger-nail” (131). As a consequence of Julia's physical contact with the objects, when Julia leaves Cassandra rearranges "curtains and chair covers" (134). She puts "Queen Morgan into a desk drawer . . [ [and] the copy of Nature World . . . into the bottom of a file labelled "Sir Percivale: Variants"” (134). While visiting, Julia presents Cassandra with a "transparent" glass snake, which Cassandra feels has a "dimension of inwardness" since "[y]ou could look at it for a long time . . . and not come to the end of it" (136). Julia needs Cassandra to accept the gift as a sign of their "reconciliation", but in doing so Cassandra has symbolically invited the snake into her room (136). The transparency of the object contrasts with the solidity of the rest of the objects in her room. This symbolises Julia's access to this new world. Cassandra's life has become transparent to her, and Cassandra is now watched in her room, ready to be consumed whole for fiction.

In a diary entry that follows Julia's visit, Cassandra writes of the "[t]yranny of objects" and has to remind herself of the "distinction between" people, "chairs, or paperweights" (167). Previously, Cassandra needed to "relate the mind and the body" (105), but now her physical world is collapsing: "I am particularly disturbed by glass objects increasingly, since that serpent has been in my possession - because they contain, being transparent, the suggestion that they are not simply solid" (167). Cassandra begins to lose her grip on reality, her thoughts that had been "securely fastened" are now "loose, floating wild and unattached" (172). She retreats from both her work and personal life. When Simon returns to England and visits Cassandra she is caught off guard by his physical presence. She feels an uncanny sense that there is "something wrong with him, something distorted, something not allowed for" (237) even though he was "not unfamiliar, she would have been hard put to it to describe the differences between what she saw and what he had imagined" (242). For Cassandra, the real Simon invades the space she had reserved for an imaginary 
Simon in her journal. By admitting Simon into her bedroom, and because of the similarities between the imagined and real Simon, her reality and her fictions collide.

The final breakdown of Cassandra occurs after she learns of Julia's novel about her life and relationship with Simon, and the prediction in the novel that Simon would visit her at Oxford. She reads a review that notes the main character, Emily, is a "lady don, cherishing and repressing an imaginative life", along with "minor Oxford characters" (273). Outraged, Simon visits her with a copy of the novel, but Cassandra has already resigned herself to its existence since "one's power lay simply in fitting one's life to one's new circumstances" (277). Cassandra is unable to see that Emily is only "Julia's image of her" (Franken 21). To Cassandra "you can both destroy and create reality with fiction. Fictions - fictions are lies, yes, but we don't ever know the truth. We see the truth through the fictions - our own, other people's" (279). Cassandra has become possessed by Julia's vision of her, and is unable to see life beyond Julia's novel. She says to Simon "[w] hat can we ever say to each other now that won't be seen in terms of Julia's fiction? Our course is plotted for us in it" (279). Franken comments that Cassandra is now "unable to keep reality and fiction apart and commits suicide" (71). To add to this, Cassandra has been made to tortuously see herself as another views her, and can now only see herself as Julia's reduced, fictional figure (284). Julia's infiltration and reduction leads to Cassandra's suicide. When this "transforms Julia's fiction into fact by accepting the image Julia has made of her" it completes the possession (Franken 72). Cassandra now lives on as Emily.

Julia

Kathleen Coyne Kelly reads Julia as "insecure and inquisitive", a child who struggles to "develop a sense of self in the shadow of her sister" (26). In her relationship with Simon, Julia believes that she did love him, if only they had "met naked, as it were. But with Cassandra watching" (102). Within context, Julia deliberately sought Simon while Cassandra was away, and took Cassandra's place as Simon's confidante. Yet, Cassandra does not watch their relationship, she actively goes out of her way to avoid knowledge about what occurred between Julia and Simon. An interpretation of Julia as inquisitive underestimates the possessive task that she sets throughout her life against Cassandra. Cassandra may have held the position of power in the Game, with Julia in her creative shadow, but their treatment of one another is not as reciprocal as Kelly implies. 
Kelly does touch on a key aspect of Julia's personality, which is that Julia "keeps Deborah at arm's length, insisting that her daughter call her by her given name rather than "Mother" - she can't bear for people to think that she is old enough to have a teenage daughter" (28). This analysis of why Julia insists Deborah use her first name is too simplistic. Rather, Julia the possessor refuses any form of possession by others. If Deborah were to call her mother then her identity becomes one that is in relation to someone else, not just her own. Julia seeks to maintain a distance from being something of Deborah's. Julia cannot be the object in another's eyes, but will find ways throughout the novel to possess so that others can be her objects.

To Julia everything is fair game, and she indiscriminately gathers material for her fictions. By filtering these experiences through her imaginative lens the process is soul destroying for her objects as they become captive to her imaginative voice. The narrator describes Julia's memory of her father as the person who read all her literature, "partly because she wanted to be assured of his approval, but partly because he was one of the few people she knew who found no difficulty in assuming that fiction was fiction" (47). Her need for approval, coupled with the phrase "that fiction was fiction", suggests Julia seeks creative justification. Her construction of a parental blessing for her creative hunting means she is aware that others close to her take issue with her approaches. Yet, even her sympathetic father is fair game and in contemplating him at his death she constructs "a chain of nearsentimental thoughts about her father as though he is a character in a novel" (48). Contrary to Julia's understanding of herself as a person who "didn't want life-reduced to its elements", her writing process stunts her ability to operate on a non-reductive level (43). She attempts to justify her reaction to her father's death because she cannot be expected "to realise what's happened, all at once" (52). When at the Quaker meeting house "Julia thought there was a short story somewhere in a Quaker meeting, but wasn't sure that she was detached enough to write it" (43). This reveals a key requirement for Julia to write: that she detach herself from her objects. When she begins to construct the narrative of her father, self-detachment has already begun as she unintentionally pursues him as a literary subject. This process extends to her daughter, and then to Cassandra when they feature in her literature. Julia's practical treatment of her father's death is tied to her self-indulgent possessive streak.

When Cassandra and Julia reconnect at their father's death, Julia invites herself to Oxford. While there she "wanted ... to see everything, absolutely everything" (129). At a dinner in the dining hall she retreats "into anonymous observation" and becomes embarrassed over some spaghetti tangled in Cassandra's necklace (130). Essentially, Julia begins 
researching for her book. She sees "her sister [as] ludicrous, even grotesque", dehumanising her, ready for her novel (130). She questions the motives of the other academics at the table: "[d]id they want knowledge or power, were they hungry for academic praise that had singled them out in youth?" (131). We are told that Cassandra notices Julia "collect[ing] their expressions with a speculative curiosity" and tries to shield her colleagues from this scrutiny by removing Julia from the environment (131). When in Cassandra's room, Julia takes her time to move around, to see the volumes of journals hidden away, the novels, including her own, on Cassandra's shelves (132). The precision with which Julia takes in these details is described as being like research and meets her need to have the physical objects in her book. It is implied that the more of Cassandra's room that she takes in, the more 'accurate' her novel will be. She bombards Cassandra with questions, wanting to know about her day, students, and work. Cassandra's responses are "dry and informative" but to have granted her this much access is enough for Julia to progress in her possession (131). Furthermore, we are shown the extent to which Julia passes judgements and makes creative leaps in her assumptions on Cassandra's motivations. She thinks Cassandra must be jealous of the girls she teaches, just as Cassaandra is "jealous of her" (134). This shows further detachment, and assumptions based on little evidence. Julia's self-involved superiority extends to the attendants of Cassandra's party. Julia thinks she reads in Father Rowell a hint of homosexuality (137). Her only indication is "something about the eyes" (137, original italics). The medievalist Nathaniel Storrin remarks to Julia: "[w]ell you will have plenty of material for an authentic book about academic life, Mrs Eskelund" (144). Considering Julia looks around Cassandra's life, her friends, "collecting tones of voice", the comment is prophetic (137). On the train home Julia realises she has "a theme for a novel . . the dangers of imbalance between imagination and reality" (149). She starts by "relating one episode to another, one incident symbolically to the next. They were all lit and glittering parts of a pattern; one took possession and in the same movement detached oneself" (148). "Pattern", "possession" and "detached" are all key words in Julia's contemplation of her proposed novel, as is the impersonal pronoun "one".

The final strike is that Julia appropriates Cassandra and Simon's relationship for her novel. This is a crucial catalyst for Cassandra's suicide. Julia's avoidance of writing about herself when she had previously drawn extensively from her home life, is tied to her possessive process. Her justification for the novel is that it will be "a way of coming to grips with Cassandra, but also of detaching us. It would be a way of seeing her as a separate individual. Knowledge, after all, was love. A lighting up of the other" (149). All Julia is 
going to create, however, is her vision of Cassandra. When Julia takes from all areas of Cassandra's life she ignores the consequences of dislodging a person from their past, present, and future. Julia fixes Cassandra's actions and thoughts in one point in time. Julia's treatment of her creative objects has been a critical insecurity for Julia's family, and it is not misplaced. The text delves into the consequences of this kind of parasitic artistry. Julia describes the characters who embody the real Cassandra and Simon as her puppets: "I just make her retreat further and further ... He comes back. I make him go" (178). The novel "demonstrates contrasting uses of the imagination and shows the impossibility of the imagination's ever fully taking in the world", but this is not required for someone to possess (Campbell 43). All Julia needed to achieve was Cassandra's sense that her world had been reduced and overtaken.

After Cassandra's death Julia finds a way to lessen her involvement. She believes that Cassandra "always made the rules. She planned the story, and I fitted in, I carried it out. She made me what I am .... She made me - take things - and then left me in possession" (288). This rhetoric is reminiscent of Clegg who blames Miranda for her own death, and moves on to a new victim. Similarly, Julia does not take responsibility for the possession, asking “[w]hy should I take possession? I don't want her life. I never really did. Certainly not now" (288). This, again, fits with Clegg's rhetoric and the cyclical nature of possession. Once she has possessed Cassandra she no longer wants or even needs her.

Jane Campbell argues that "Cassandra's papers have power: the last journal entry is read out at the inquest, and the papers taken from her room became the final image of The Game" (50). When Simon and Julia drive away from Oxford, in the trunk of the car "closed into crates, unread, unopened, Cassandra's private papers bumped and slid" (286). Campbell suggests:

The papers' continuing existence, like that of the Game in the window seat, undercuts the apparent optimism of what immediately precedes Julia's determination to be a new woman, free of Cassandra and Simon and of the judgments of the past. Cassandra's papers, with their capacity to hurt Julia but also perhaps to educate her, refute Julia's naive hope and suggest that genuine growth is more difficult and less tidy than her idea of it. (50-51)

What this argument does not allow for is that the papers are "closed into crates, unread [and] unopened" (295). Julia is given the abstracted Cassandra she always wanted when she has access to these papers. She has the records from which she can now continue to 
produce her narratives. Creighton argues that in creating "a composite creature, in a way a sort of binary fusion" (146)" in her novel, Julia "merge[s] with Cassandra" (23). Again, this seems to ignore the lack of reciprocity evident in their relationship. Their relationship is not a fusion, but a possessive absorption. What Campbell and Creighton do discern is the valid possible reading of negative dual possession. Although she does not claim it, Campbell's argument is about a kind of possession when she suggests that the papers have a capacity to haunt Julia for the rest of her life. Nonetheless, this does not strictly align with the possessive process that has been portrayed in the novel. Julia has been rewarded in the possession, even if she no longer desires it. The papers are suppressed by Julia; she is not as much haunted by them as she now owns them, and the Cassandra of the journal is now at her mercy. When Cassandra retreated from the world into her private room it was by choice. Her experiences explored through her writing are now contained within boxes in a car, with no after-life. Once Julia possesses Cassandra, once she has ingested her like a snake, she becomes creatively complete and produces her best novel. Julia has "won the game" (St. Clair 35). 
The main character in The French Lieutenant's Woman is Charles Smithson, a gentleman of leisure who is engaged to Ernestina Freeman. During their stay in Lyme Regis, he encounters a mysterious and enticing woman named Sarah Woodruff. This forces Charles to "exercise his free will by making a choice" between "Victorian convention (Ernestina) and . . existential freedom (Sarah)" (Dodson 297-8). The novel features a number of secondary characters that claim our attention, including the ambitious Sam Farrow (Charles's valet), Aunt Tranter (Ernestina's Aunt), Mary (Aunt Tranter's maid and Sam's eventual wife), Mr Freeman (Ernestina's father), Dr Grogan (the local doctor and Charles's confidant), and Mrs Poulteney (a cruel widow and Sarah's employer).

In this novel Fowles displays his literary prowess. It is neo-Victorian and thus read as a historical novel, metafictional through the narrator's addresses to the reader and commentary on his characters, intertextual through the chapter epigraphs and literary parallels, and it parodies Victorian conventions, and critiques traditional expectations of masculinity and femininity. ${ }^{12}$ Because of this, the novel is often defined as postmodern. This has afforded scholars the opportunity to apply any recent critical framework. In John Fowles: a reference companion, James Aubrey dedicates a chapter to the "Critical Approaches to the Fiction" (141). The chapter is broken into seven key fields that are recurringly applied to Fowles's work: Biographical, Psychological, Deconstructive, Historicist, Feminist, ReaderResponse, and Formalist (142-51).

The purpose of this chapter is to reassess Charles Smithson and Ernestina Freeman by noting the forms of possession in the characters' lives. This chapter is divided into sections on Charles Smithson and Sam Farrow, Ernestina Freeman, and concludes with a discussion of the conflicting readings of Sarah Woodruff.

To possess is to exert power, and so the concept of power naturally manifests through the different forms of possession in the novel. There is a clear possessive power dynamic based on class between Charles and Sam. Gendered power is exhibited between Charles and Ernestina, and Charles and Sarah. Furthermore, we see the power of Victorian society to possess individuals; Ernestina is oppressed by the expectations of a woman in her class position. While the focus of this chapter is on characters that interact within the story, and I did not feel the narrator's passing encounter with Charles on the train was enough to qualify

\footnotetext{
${ }^{12}$ Mahmoud Salami's John Fowles's Fiction and the Poetics of Postmodernism is particularly engaging for its analysis of the narratological innovations in TFLW.
} 
for this, it is still pertinent to succinctly assess the narrator's relationship to possession and power when he is such a contentious figure.

Scholars fall into one of two camps: either the narrator is Fowles or he is not. I subscribe to the second interpretation. Patricia Duncker suggests that the omniscient narrator is "Fowles, thinly disguised" (258). Mariadele Boccardi comments on "Fowles's trick of writing himself into the final chapters of" TFLW (30). When the narrator physically manifests he is described as a man in his forties, bearded, and "decidedly unpleasant" (406-7). I argue that this compounding of Fowles's countenance with the narrator character is designed to play with expectations around narrative authority. The purpose of the narrator is to "disrupt the illusion of reality ... to permit an investigation of its status as fiction" (Holmes, "Paradox of Omniscience" 184).

Reading Fowles as the narrator can drastically alter the narrator's textual significance, and can be too simplistic to account for the narrator's complexities. Ellen Pifer says that the narrator's 'insist[ence] . . on both the novel's illusory reality and the characters' autonomy struck many readers as contradictory" (9, original italics). The narrator interjects that the story is "all imagination" and "the novelist stands next to God", but then relays that "it is only when our characters and events begin to disobey us that they begin to live" (95-6).

Throughout the text, the narrator suggests his characters have freedom, but takes this away when he "makes a small adjustment to the time" (465). The narrator turns the clock back, thus reversing the romantic reunification of Sarah and Charles, which changes the ending (465). The narrator, speaking in the third person at the end of the novel, "regards the world as his to possess and use as he likes" (465). The novel is thus framed by a possessor. As Cassandra says in The Game "[y]ou can both destroy and create reality with fiction", but this is only a replication, an illusion, of reality (279). We possess what we create, and in creating the fictional world the narrator has possessed all within it.

\section{Charles}

Charles has a specific interest in the collection and study of fossils, and his search for fossils is a part of why he accompanies Ernestina to Lyme (46). Charles's fossil collecting is pertinent to his characterisation. His object of choice represents his own social fossilisation, specifically his inability to grow with the "social evolution [that] begins to favor the mercantile class" (Wagner 35). Also pertinent to Charles's characterisation as "the scientist" is his belief in Darwinism (11). Charles calls "himself a darwinist", but the narrator instead 
associates his actions with the earlier "Linnaean obsession with classifying and naming, with fossilizing the existent" (50). The narrator claims that "we can see it now as a fore-doomed attempt to stabilize and fix what is in reality a continuous flux" (50). Jill Wagner reads Fowles's Victorian scientist and "the very real struggle with early Darwinism" as manifesting through "the scientist's conceptions of his own class" (33). Charles believes "undoubtedly [that he belongs] to the fittest" (165) and Wagner observes that Charles's "identification with 'the fittest' is due partly to his sense of societal position" (35). Even if he is descended from monkeys "he considers himself a "titled ape"” (Wagner 35). Darwinism replaces religion to fulfil Charles's desire for a "reassuring orderliness in existence" (50). However, this orderliness relies on the classification of other people to satisfy his own need for "selfidentification" (Wagner 33). If fossils represent his stagnation, then Charles's interpretation of his place in the Darwinian world exemplifies this stagnation in practice as it allows him to retain his social position without guilt and to sustain his sense of power over other characters in the novel, specifically Sam, Ernestina, and Sarah.

In TFLW characters who recognise that their social status leads to 'possession' are able to attain freedom through their adaptability. David Landrum notes that the "parallel plot" of Charles and Ernestina and Sam and Mary "closely focuses on class conflict and illustrates the tensions that arise from social stratification" (104). Charles exhibits possessive tendencies towards anyone that is socially beneath him, such as women and servants. In their relationship, Ernestina is under the illusion that she possesses Charles through their engagement. In the same way, Charles assumes that he possesses Sam, and that he will later possess Sarah. This may be true in an economic sense, but Sam does not allow Charles to dictate his future. The narrator informs us that "Charles had many generations of servanthandlers behind him [and] . . could not have imagined a world without servants" (44). In comparison, because the "new rich" could remember a time before servants they tried turning "their servants . . into machines" (44). Charles sees Sam as "partly a companion - his Sancho Panza, the low comedy" (44). He keeps Sam because "he was frequently amused by him; not because there were not better 'machines' to be found" (44). Landrum says that "[ $t]$ he narrator assures the reader that Charles is a benevolent master to his servant, that he feels a certain amount of fond affection for him, [and] does not exploit and mistreat him" (105). Yet, this does not negate his condescending attitude towards Sam. My reading is that the narrator's comments are a sarcastic nod to Charles's lack of benevolence, that he is perhaps even worse than the new rich. Although Landrum's article is strong overall, it seems that he has missed the sarcasm as his analysis treats the narrator's comments seriously, while he also 
highlights Charles's derogatory treatment of Sam (105-6). I argue that Charles's treatment of Sam is built on an effort to reduce him to a different kind of machine: an object of pleasure. Charles expects Sam to do his duty as his valet. He may not be reduced to a working machine, but he is expected to provide entertainment. What Charles thinks is a more personal relationship between them is more of an appropriation of the Sam 'character' that Charles has created. One could suggest, perhaps controversially, that those who are reduced to machines are at the very least able to sustain an identity outside of their employment. They can separate themselves from the utility that they provide.

Charles is entertained by exerting a kind of sadistic power, meaning that the pleasure of their relationship comes from his feelings of having possessed his valet. For example, Charles plays a cruel joke on Sam, telling him that he is to leave Lyme and "return to Kensington" because he is "up to no good" with Mary (109). The narrator describes how the silence that follows Charles's initial order "would have softened the heart of any less sadistic master" (109). This interaction has a clear negative effect on Sam who says that he is "appier ere.” (109). Charles seems surprised at Sam's reaction and their interaction takes an even more condescending turn: “"Now what is wrong?' 'Er, sir.' 'Ursa? Are you speaking Latin now? Never mind, my wit is beyond you, you bear"' (110). Sam's hand trembles and he tells Charles, "with a choked voice... 'We're not 'orses. We're 'ooman beings."” (110). Landrum nicely summarises Charles's general treatment of Sam:

Charles "benignly bull[ies] his servant, quoting Latin to him, accuses him of being drunk, reminds him that he was 'born in a gin palace' (40), calls him a Cockney, and, after declaring he is being too 'fast' with Mary, tells him, 'if you're not doubly fast with my breakfast, I shall fasten my boot onto the posterior portion of your miserable anatomy' (40). Charles's attitude is glib, condescending, shallow, [and] smugly superior. (105).

The power that Charles exerts over Sam is directed towards his possible future happiness because to leave Lyme Regis would be to leave Mary. Part of Charles's intention is to apparently protect Mary's "gentle trusting . . . heart" (110). When Charles bribes Mary because she has seen him in the Undercliff with Sarah, the narrator says, "[w] hat can an innocent country virgin know of sin?" (267). I suggest this is focalised through Charles's view of Mary as the narrator later reveals that Mary is in fact not "an innocent country virgin" and Charles's protection of her is based on his lack of understanding of the lower 
classes and women (272). Thus, Charles does not only try to control Sam's present, but also his future, placing himself in the position of God. With the novel's developments it becomes clearer that Charles only sees Sam in relation to himself as the object to his subject. When Sam expresses his hopes of owning his own shop Charles says, "besides, Sam, I'm used to you . . . fond of you. I'm damned if I want to lose you."” (330). Charles warns Sam that “once you take ideas above your station you will have nothing but unhappiness. You'll be miserable without a shop. And doubly miserable with it" (330). Charles's concern is a result of his own superiority complex and inability to accept a changing social order. It is also a result of being unable to see others as existing outside of his personal sphere. That Sam should have aspirations beyond serving Charles is incomprehensible to him. Ultimately, his previous feelings about losing Sam contradict his later outlook that Sam is "like all servants, dismissible" (375).

However, conscious of Charles's need for superiority, Sam employs tactics to satisfy this. As if aware that "Charles termed to himself" the role of "Sam the footman", a servant with a "profoundly respectful obedience to his master's behests", Sam often reverts to this to stay in Charles's favour (208). When Charles eyed Sam he "reverted to his humblest footman self and stared intently at his master's boots" (259). Sam knowingly plays his part to temporarily appease his “master" (40). Sam's aspirations beyond being a servant are apparent through his "sharp sense of clothes style - quite as sharp as a 'mod' of the 1960s; and he spent most of his wages on keeping in fashion" (43). The narrator notes that "of course to us any Cockney servant called Sam evokes immediately the immortal Weller" from Charles Dickens's The Pickwick Papers (42). The difference, we are told, is that Sam Weller "was happy with his role", but Sam Farrow "suffered it" (44). Landrum explains that this is because "Sam [Weller] is rescued from his penury by the benevolent Pickwick, and his eventual loyalty to his master, his willingness to follow him even to jail, is probably a romantic accommodation of an unpleasant social actuality. Sam Farrow's situation with Charles is not romanticized" (106). In addition, Sam is actively fighting against Charles's possession, and by maintaining his identity outside of the one Charles appoints him he is able to evade the abstractive process so that he never becomes reduced to Charles's 'Sam'. Furthermore, Sam takes back control by intervening in Charles's life when he does not deliver a letter to Sarah (404). This becomes a catalyst for Charles's frantic but hopeless search for her after she disappears. Sam leaves Charles's employment, marries Mary, has children, and because he "played his cards very right in Lyme" (423) he is able to enter the employ of Mr Freeman and succeed as an "indispensable member of the window-dressing 
staff" (426). Sam is no longer replaceable. Sam represents a rising class, whilst Charles is a part of a stagnated group, but Sam must make one final gesture to be free of Charles completely. When Mary exclaims “Twas ‘er, Sam. I saw 'er clear as - I can't hardly believe it" (422), Sam is confronted by his "conscience" (426). The narrator says that "[t]he Faust myth is archetypal in civilized man; never mind that Sam's civilization had not taught him enough even to know who Faust was, he was sufficiently sophisticated to have heard of pacts with the Devil and of the course they took. One did very well for a while, but one day the Devil would claim his own" (426). Sam chooses to provide information on the sighting of Sarah, which not only further inverts their roles in one another's lives, so that Sam is moved into the position of power over Charles's future, but it is Sam's final bid for independence so that he is no longer followed by his Devil.

One of Charles's favourite pastimes - the collection of women - provides some fulfilment during his life as "a young bachelor" (16). Beyond already being in the dominant position of male and upper class, the " $8,155,000$ females of the age of ten upwards in the British population" compared with "7,600,000 [eligible] males" places Charles in a higher position of power over the array of women presented to him (Fowles 6). Yet, despite having women come to him, Charles is not an idle bystander, he "quite liked pretty girls and he was not averse to leading them, and their ambitious parents, on" (18). He is able to "sniff the bait and then turn his tail on the hidden teeth of the matrimonial traps that endangered his path" (18). He actively tempts women, allowing them to believe they have a chance at marriage - a cruel power play - before discarding them when he is done. He may use them as entertainment and to bolster his ego, something we also see in his cruel treatment of Sam, but his inability to commit to any of them is because his possessive hunt is unfulfilling when the women are too easily attained. But, meaninglessness again creeps in on Charles and he starts to worry that he is becoming a lonely, ageing bachelor "like his uncle at Winsyatt" (81). Charles acknowledges that travelling had appeased his need for a wife because it allowed him "to take an occasional woman into his bed" and so his sexual drive was still fulfilled (82). When travelling no longer attracts him, women still do (82). However, he is left "in a state of extreme sexual frustration" because he will not allow the possibility of sex "to dictate the reason for a journey" (82).

When Charles met Ernestina she presented herself as a solution to two of his problems. Firstly, Ernestina teased and feigned disinterest in him, and did not make the supposedly "cardinal error" of pretending to share his interests (79). Of course, this disinterest is just as choreographed as the other women's interest, but Charles easily feeds 
into this as he later does with Sarah. At that point in their relationship Ernestina held some power over Charles who is easily manipulated. Her later benign surrender to her husband to be, however, quashes the small amount of power she had held. At that stage, Ernestina was a respite from the wealth of women who had been gifted to Charles because she created the illusion of requiring effort to capture. Thus, she engaged his possessive tendencies by being the "prize[d] "specimen" to enrich his "fossil collection", a specimen that provided the thrill of the hunt prior to possession (Wagner 38). Secondly, Ernestina was an offer of steady sexual intercourse. We can link Ernestina to his sexual motivations because the explanation of his "extreme sexual frustration" and the realisation one morning that "[h]e loved Ernestina" occur on the same page (82). The late-Victorian feminist Mona Caird said of marriage that a woman "figured as the legal property of man", that "absolute submission on the part of his wife" was expected, and she was treated as "the bearer of children ad infinitum" (81, original italics). Therefore, the fact that marriage offers Charles "another chance to be a dominant figure and to procreate, ensuring the survival of his name through blood", does not run counter to the novel's period setting, nor does Ernestina's submission to Charles (Wagner 38). Furthermore, Caird says "women originally became the property of man by right of capture; now the wife is his by right of law" (72). Caird idealises medieval marriage here, but I suggest that Charles is attracted to both the right of capture, and to hold a woman in the eyes of the law; the first represents the act of collecting, the second the possession. When Charles ruminates on Ernestina's "demure, sweetly dry little face asleep beside him" it may appear innocent, but it plays into a romantic fantasy, that Ernestina also creates, which makes their engagement more palatable (82). This masks the reality that their marriage is an economic transaction, with sexual and reproductive possession as a condition of that contract.

Charles's married life with his perfect specimen, Ernestina, may offer stability, but it is clear as the text progresses that he views this future as having "impending sacrifices" (117). I propose that this disillusionment can be read as a result of his possession of Ernestina. Charles thinks "she was only a woman. There were so many things she must never understand: the richness of male life, the enormous difficulty of being one to whom the world was rather more than dress and home and children... whether Ernestina would ever really understand him as well as he understood her" (12, original italics). When he begins seeing Sarah, he chooses not to tell Ernestina because "he foresaw only too vividly that she might put foolish female questions" to him (165). That she "had neither the sex nor the experience to understand the altruism of his motives" (165). This highlights Charles's hypocrisy and 
self-denial. Charles's general views of women as submissive, which align with the Victorian cultivation of women's ignorance, are a social commentary on male dominance and female subjugation. Caird explains that women were educated "with what can only be called ferocity, to do their 'duty' patiently, silently, devotedly, and to remain thus meek and submissive under the severest provocation" (83). Furthermore, in an interpretation of Manu that Caird feels aptly describes English women she says "the true woman has no interests separate from those of her home" (96). Therefore, Charles's assumption that Ernestina can never understand him, or understand the world beyond her appearance, home, and offspring, is insensitive to the reality of what would have been her education. Fletcher, noting this as being a result of her Victorian repression, says that Ernestina is an "absolutely knowable woman" (34). Fletcher's argument is only supported by siding with Charles, who believes he has gained a full understanding of Ernestina (Fowles 12). What I propose is that Charles is beginning to experience a post-possessive low after the high of the collection. Like an addict, Charles's collecting vice is continual, and Ernestina is no longer fulfilling that vice once she is in his possession. The novel also reveals Charles's contradictory expectations and disappointments. Charles is drawn to Ernestina's outward appearance - when she blushes (151), her dress, her "tender little white body" (266), all of which cause "a distinct stir in his loins" (267). The Victorian writer Sarah Stickney Ellis wrote that "[a] careless or slatternly woman, for instance, is one of the most repulsive objects in creation". Ernestina is fulfilling her duty to uphold an appearance that "render[s] herself an object . . of affection" (78). Charles begins to notice that "there was something shallow" in Ernestina, "beneath the demure knowingness, something of the automaton about her, of one of those ingenious girlmachines from Hoffmann's Tales" (151).

The contradiction of this is that Charles's hunger for Ernestina is based on her appearance, but he becomes disillusioned by the inauthenticity required to create it. Academics have long seen Sarah as synonymous with freedom. Charles has a "great vision of himself freed from his age, his ancestry and class and country ... [and] freedom was embodied in Sarah; in the assumption of a shared exile" (430), "[w]hereas Charles and Ernestina are bound by elaborate convention" (Landrum 108). On the other hand, Ernestina is always read as the symbol of convention, the figure inhibiting Charles's freedom. If reading the novel in existentialist terms, or as a critique on social norms, then it is easy to see how Sarah and Ernestina become the juxtaposition between freedom and captivity. My intention is not to deny this dichotomy, but reviewing the theme of possession offers a more focussed way of understanding the relationships between characters. In particular, it highlights the 
nature of the subject-object relationship that stems from Charles's solipsism. Charles shows how one sees others as extensions of themselves. With this comes the realisation that although Charles becomes open to the knowledge that a marriage with Ernestina would mean stagnation, what is overlooked in the critical material is his progressive dehumanisation of her. To Charles she had been an intriguing woman to capture. In his possession she became his pretty object. Once he begins his 'capture' of Sarah, who is a new means to fulfil his collecting vice, Ernestina becomes the automaton, a "deception in the flesh" (190). Even though Charles breaks his engagement to Ernestina, by this time he has collected, abstracted, and discarded her, she 'faints' to the floor, the "catatonia of convention" (386). In this way, Charles performs a similar process on Ernestina as Clegg does on Miranda, and Julia on Cassandra.

Charles attempts to reduce and abstract Sarah but fails to possess her. Through Sarah, Charles seeks a fantasy quest that briefly frees him from his social constraints. Barnum describes the goal of the "journey or quest" in Fowles's oeuvre as the "ability to know and experience love" (2). This may be the case for other Fowles texts, but for Charles I argue that his "mythic quest" is less about experiencing love, and more about achieving a "wholeness" that is based on his subjugation and reductive fantasies of others (Barnum 5-6). With Ernestina now possessed, Charles is driven to seek another and finds that object in Sarah.

Charles turns Sarah into an object from the start of the text, seeing her only as a "black figure" (9). Ernestina reveals that the people of Lyme Regis call her "the French Lieutenant's . . Woman", to which Charles openly admits his intrigue: "Who is this French lieutenant?" (9). Marias says that "the various names for, and interpretations of, Sarah fail to identify, and so explain or contain, her" (248). The introduction of a depersonalised and desexed figure, with a name suggestive of her sexual misconduct, prefaces Charles's sexual fascination with her. It also introduces the nature of his treatment of Sarah - she is a blank slate that ignites his collecting impulse, a woman onto which he will project his fascination with science and sex. When Sarah turns to look at Charles he feels like she looks "through him" (10). Olshen reads "Sarah's glance as like ... [the] familiar image of love's arrow" (68). This is overly romanticising, but the concept that Sarah's glance pierces Charles in some way is certainly applicable and Charles can now not free himself from her "unforgettable ... tragic face" as "again and again, afterwards, Charles thought of that look as a lance" (10).

Charles moves through a number of considerations of Sarah, which indicates an inability to fix his understanding of her. When he comes across her sleeping in the woods "he 
thought he had stumbled on a corpse" (70). While watching her sleep he sees "something intensely tender and yet sexual in the way she lay; it awakened a dim echo of Charles of a moment from his time in Paris. Another girl, whose name now he could not even remember, perhaps had never known, seen sleeping so, one dawn, in a bedroom overlooking the Seine" (70). Even though she reminds him of his sexual experiences, he soon moves on to "not sexual, but fraternal, perhaps paternal" feelings towards her (71). Sarah is also compared to a child. When she is sleeping "her right arm [is] thrown back, bent in a childlike way" (70). At a later point Charles feels that "for a moment she was like a child, both reluctant and yet willing to be cozened - or homilized" (184). This recalls Charles's feeling that Ernestina "is a child among three adults" (150), and their kiss is "as chastely asexual as children's" (83). What Charles works through are different ways to define, and thus, possess Sarah. He progresses from associating Sarah with those he has sexually possessed, to the conflation of a woman with a child-like status. This evokes marriage in a time which saw the protection of the woman passing from father to husband. Furthermore, Charles shifts in his vision of her to something more scientific. This introduces a quest concept of Sarah as both his maiden, fulfilling his possessive drive for women, and a beast, fulfilling his scientific endeavours.

Charles begins to feel he understands her as the outcast, her loneliness, and despair and reads in her eyes that they are "perhaps not untinged with shame" (71). Charles's struggle to understand Sarah plays into the collecting desire. If she cannot be easily unpacked he must work harder to be able to reduce and possess her. When visiting Mrs Poulteney's house where Sarah works he is "intrigued to see how the wild animal would behave in these barred surroundings" (103). He describes the private looks that pass between them as such: "it spoke worlds; two strangers had recognised they shared a common enemy" (106). The narrator notes that he also believes that "[f]or the first time she did not look through him, but at him" (106). With this comes Charles's assumption that he is beginning to understand her. As with Ernestina, he dehumanises Sarah, so that she becomes a scientific object for analysis. He now has a "a scientific as well as a humanitarian reason" for helping her (165). Dr Grogan, the local Irish doctor, perpetuates Charles's need for fixed meanings. The inhabitants of Lyme see in Sarah what most concerns or interests them, and so Dr Grogan thinks of Sarah as a scientific problem to be understood in those terms. For example, Charles refers to her as a "specimen of the local fauna" (154). Charles now thinks he has a means through which he can comprehend her to complete the possessive quest.

The relationship between Charles and Sarah gradually develops through their interactions in the woods. There are times when Charles glimpses what is likely a more 
accurate version of Sarah's personality. She contradicts his opinion and "assume[s] some sort of equality of intellect with him" (143). In these moments Charles views her in mythical terms, as a "Calypso" come to capture him (143). "He knew he was about to engage in the forbidden, or rather the forbidden was about to engage in him" (147), which shows there is a give and take to the possession between Sarah and Charles. Despite this, Sarah makes sure to appeal to Charles's need for power. When she reveals details of her relationship with Varguennes she asks him "Then you forgive me my sin?" (182). Sarah seduces Charles with the opportunity to act with the power of a God to forgive her sins.

The sexual tension between Sarah and Charles builds until he visits her at the Endicott's Family Hotel. Sarah has sprained her ankle, which means Charles must enter her room to see her as she cannot come down the stairs. In her room Charles is confronted by his contrasting visions of her. He thinks she is "proud and submissive, bound and unbound, his slave and his equal (349). He is "overcome with a violent sexual desire . . . Her defenceless weeping was perhaps the breach through which the knowledge sprang-but suddenly he comprehended why her face haunted him, why he felt this terrible need to see her again: it was to possess her, to melt into her, to burn, to burn to ashes on that body and in those eyes". (350). After their brief sexual encounter they lie in silence until Charles is distressed to discover that "[h]e had forced a virgin" (357). Charles views their sexual encounter only in terms that relate to himself. The first is his sexual possession of her - their fusion as one that destroys their individual identities. The second is his alarm at having forced her, despite Sarah being a willing participant in the sexual relationship. This is another instance of removing women's agency. To Charles the onus is on his actions and Sarah was only a passive party in the scenario. However, Sarah then exerts her power over Charles when he realises her deception. She had lied about her relationship with Varguennes, "[t]o put him totally in her power" (357). To this Sarah acknowledges her actions, "Yes. I have deceived you. But I shall not trouble you again" (358).

After leaving and processing this revelation, Charles continues to find ways to comprehend Sarah. He thinks that Sarah "knew he loved her; and she knew he had been blind to the true depth of that love" (371). By now she "would have wept herself to sleep; he would let her suffer one more black night; but she should wake to joy" (374). After breaking off his engagement to Ernestina, Charles believes that "[h]e and Sarah were not yet carved into that harmony; but they were of the same stone" (403). The fossil imagery signifies that Charles is still in a place of stagnation. He may be freeing himself from social constraints, but his views of the world and others are still fossilised. This is more apparent when he makes 
arrangements for a new life with Sarah. Charles believes he has possessed her and is now capable of dictating her life by making practical arrangements. Sarah must be "suitably installed in London" before they go abroad to "lie awake, in each other's arms, infinitely alone, exiled, yet fused in that loneliness, inseparable in that exile" (403). However, Sarah disappears. Feeling defeated, Charles finds palaeontology "too emotionally connected with the events of that fatal spring", and makes donations to the Geological Musesum" who had the pick of the collection that was in a family home called "the Kensington house", "the rest he had given to his students" (428-9). This represents a phase of Charles's journey in letting go of his possessions, even if he is not able to fully achieve this yet.

When Charles finally finds Sarah he assumes she is working as a governess (442), but discovers she is a "New Woman", "electric and bohemian", still "rejecting all formal contemporary notions of female fashion" (446). Sarah now works with Dante Gabriel Rossetti as his "amanuensis. His assistant" (448). On a wall, Charles notices "a row of hooks, from which hung a multi-colored array of female dresses, scarves, shawls" (447). Charles asks if she "serve[s] as his model?" to which she replies "sometimes" (448). It is then that Charles notices "one of the sketches on the table by the door. It was of a female nude, that is from the waist up, and holding an amphora at her hip. The face did not seem to be Sarah's; but the angle was such that he could not be sure" (448). Charles is still projecting his sexual imagination onto Sarah by assuming the nude is her. Landrum points out that the "possibility of sexual expression is ... something that seizes Charles" because she is still a sexual figure in his eyes (109).

Furthermore, Sarah reveals to Charles that there is someone else who wishes to marry her, but she does not want to marry him or Charles: "I do not wish to marry . . . I do not want to share my life. I wish to be what I am, not what a husband, however kind, however indulgent, must expect me to become in marriage" (453). This revelation showcases the choices that Sarah is able to make to sustain her freedom. Sarah sees herself as having "no genius" other "than the capacity to aid genius in very small and humble ways" (453). This resonates with her adaptability throughout the novel. If total freedom for a woman is unachievable because of her time period, then Sarah can still find autonomy through playing characters, something I suggest she is still doing as a 'new woman'. If she is currently the artist's muse he can artistically create her, but she is still a woman adapting. When Charles tries to reason with Sarah he says "[b]ut you cannot reject the purpose for which woman was brought into creation" (454). This calls into observation Charles's previous feelings on women and their role in society. He is still desperate to possess Sarah in a traditional 
marriage and family sense. In the first ending Charles meets his and Sarah's daughter Lalage. There is an implication that he and Sarah will be together in the future. In the second ending there is no revival of their relationship. Rankin argues:

[The] two endings . . . complete the set of choices made available to Charles. Whereas the traditional ending was the one Charles's Victorian gentleman self might have chosen, the second, or romantic ending, is the one his other self would select. That other self is the side of Charles which has been attracted to Sarah throughout the novel, and ... it is motivated as much by repressed sexuality and emotion as by intellectual affinity. (203-4)

In Charles's romantic ending Sarah chases after him, "[g]athering her skirt in one hand" she blocks his exit: "I cannot let you go" (457). This is not the final ending. It is only a wishful, romantic scenario. Sarah's submission to Charles goes against her bid for freedom. In marriage she would be his possession. Richard Lynch interestingly comments that the "ending presents the reader with, supposedly, a different Sarah from the first, but is she really different? There is no textual evidence for it. There is only evidence that Charles's view of her has changed" (69). This supports the reading that this ending is also Charles's fantasy. After his long search for Sarah it is unsurprising that he desires that she pine for him so that he can solve the enigma in his mind. The third ending (or the second ending with Sarah) is more consistent with Sarah's characterisation and places her back in the position of power when she does not rekindle their relationship. In this ending Charles:

[S]aw his own true superiority to her: which was not of birth or education, not of intelligence, not of sex, but of an ability to give that was also an inability to compromise. She could give only to possess; and to possess him-whether because he was what he was, whether because possession was so imperative in her that it had to be constantly renewed, could never be satisfied by one conquest only, whether . . . but he could not, and would never, know - to possess him was not enough. (468)

Lynch comments that critics have relied "on the double ending as evidence of existential themes" (68). He is worth quoting at length to assess the trend in reading the novel because it can alter how we interpret Charles: 
McSweeney declares the two endings necessary in an 'existential' text to avoid confirming belief in an 'overall plan' in things (141). John Neary, echoing McSweeney, believes that the double ending undermines the narrative voice's 'godlike powers,' since a single ending would be 'authoritative' and would not allow Charles his freedom. The absence of a single, clear ending makes the book 'an existential affirmation-of freedom' (Neary 175). Acheson sees Charles as achieving a measure of authenticity in the second ending because there is no 'providence' or 'intervening god there (45)' ... All of these critics appear to hedge their bets on connecting Charles directly with existentialism: they locate existential freedom in the structure of the narrative rather than in the character, or if they see it in Charles, it is 'unconscious' or a 'measure' of authenticity, or yet to be fully realized. (68)

Fowles often conveys existentialist philosophies through his novels. Fowles asserts that The Collector and The Magus "were both based on more or less disguised existentialist premises" ("Notes" 17). However, if we understand possession to be at the core of Charles's motivations, what has been read as the existentialist ending does not necessarily hold up. When Charles talks of Sarah as a possessor it is a commentary on himself. In his anger at Sarah's refusal to be possessed he makes a final attempt to classify Sarah, to reduce her, and thus understand all of her actions. In doing so, I argue that he reveals his own intentions. This does not dismantle existentialist readings of the ending, but what it does show is that relying on the existence of two endings is not enough to convincingly argue for Charles's existential development. How we interpret the ending depends on whether one reads this epiphany as leading to his freedom (existential), or, as I suggest, as evidence that he has still not developed the self-awareness to break his possessive cycle (possession).

\section{Ernestina}

Ernestina Freeman is the daughter of a wealthy, middle class man who owns a chain of clothing stores on the West End. Dressing "in the height of fashion" (4), with a delicate step (5), and "exactly the right face for her age", on appearances she is the perfect Victorian wife to be (26). And yet, as our narrator explains, she is only "so very nearly one of the prim little moppets, the Georginas, Victorias, Albertinas, Matildas and the rest who sat in their closely guarded dozens at every ball” (27). The early metafictional allusion to Ernestina's face as "small-chinned, oval, delicate as a violet", like the faces that appeared in the works of 
Hablot Knight Browne (Phiz) and John Leech, introduces a constructed quality to her character (26). Her colourful clothing is intentionally attention-grabbing "to compensate[] for so much else in her expected behaviour" (5), and her idealised pale skin and "grey eyes" become further markers of her generic looks and personality, something her clothing also compensates for (26). Olshen's description of Ernestina is accurate, although notably unsympathetic: "[she is the] spoiled, pampered, self-centred only child of a very wealthy London draper" (73). He claims that "unlike Sarah, Ernestina is exactly what she seems, the possessor of all that the masculine society of her time required of its ladies" (73). Having been published in 1978, Olshen's John Fowles is somewhat outdated. Nonetheless, as an early contributor to Fowles scholarship his argument suitably describes the trend of disregarding Ernestina as "vapid", "insipid", and the stereotypical Victorian woman (Rankin 198). More importantly, she is deemed the foil to Charles's free status and communion with Sarah Woodruff.

Conveying "not perceptions of her own, but those of her community which she derives from rumor and gossip" (Marais 247), Ernestina introduces Sarah to Charles as "poor Tragedy" (9). The irony in this is that Ernestina is herself a tragic figure of imprisonment. I argue that Ernestina has often been usurped of her tragic status by critics who read Sarah as the more conventionally tragic woman assigned as the "French Lieutenant's Woman", and, I suspect, as a result of her unsympathetic characterisation (9). Whilst she does enact a "physical and intellectual demeanor [that] corresponds... to her society's expectations", Olshen's claim that she possesses this is not an appropriate word considering her situation (Lenz 104). Rather, she is possessed by the expectations of her society, and as a result develops an overtly constructed persona. When Pamela Cooper seems to expresses contempt at the narrator's condescension towards Ernestina's "banal diary entries", she displays the scholarly disregard of Ernestina by not engaging with the parody in the work (137). The novel features literary parallels of Ernestina with the socially aspirational "Becky Sharp" from the nineteenth-century satire Vanity Fair, and Cecily Cardew from The Importance of Being Earnest (Fowles, "French" 27). The treatment of Ernestina's diary resembles that of Cecily's, and the offhand comment to Charles, "if you were only called Lord Brabazon Vavasour Vere de Vere- how much more I should love you!” (79), resembles the recurring joke of Cecily and Lady Bracknell's dream "to love some one whose name was Ernest" (Wilde 284). TFLW is rife with intertextual references, but these few examples hint that we should approach the novel, and Ernestina in particular, as a social satire. Her conditioned behaviours are parodied to highlight contempt for the modes of confinement she faces. 
Brooke Lenz suggests that Ernestina is "thoroughly conditioned by and comfortable within her social location" (105). However, the reference to Becky Sharp, along with her manufactured behaviours, indicates that Ernestina has been conditioned to climb the social ladder. She also exhibits insecurity about her class position in her relationship with Charles, showing that she is often uncomfortable within her social location. "Her father was a very rich man; but her grandfather had been a draper", whereas "Charles's had been a baronet" (8). This difference in family history is a point of class-contention in their relationship. The Freeman's "represent the rising entrepreneurial class in England" (Landrum 104). Her and Charles's “impeding marriage is indicative of the alliance of old money and new that was occurring in industrial England at the time" (Landrum 104). Names in Fowles are loaded with meaning, and with the meaning of earnest being "seriousness", that is certainly reflected in the serious financial and class aspirations of the Freeman family ("earnest"). The name Freeman can be interpreted in relation to the family having become financially free through the success of the grandfather, and free of the working class through the marriage of Ernestina's parents because Mr Freeman "married discreetly above him” (79). Mary Dodson notes the irony of Ernestina's surname because she is "enslaved to the dictates of Victorianism, not a 'free man' at all, much less a free woman" (297). As Ernestina's family has attained financial freedom, their position has meant that Ernestina is possessed by her desire to attain perfect Victorian womanhood, and to further elevate her class position.

When the narrator claims that "Ernestina's qualms about her social status were ... rather farfetched, even by Victorian standards; and they had never in the least troubled Charles", he reveals his unreliability reporting character's feelings truthfully, or to even report them at all as is the case with Sarah (79). If one is to take the narrator's indirect report at face value then perhaps Charles does not care at this point. Considering the humorous tone of the novel, I propose that the line is another instance of sarcasm, and that Charles only comes to openly convey class snobbery in relation to Ernestina that already existed. Prior to this, Charles finds Ernestina's "irresistible" as she works to possess him through her appearance and behaviour (26).

[A]t first meetings she could cast down her eyes very prettily, as if she might faint should any gentleman dare to address her. But there was a minute tilt at the corner of her eyelids, and a corresponding tilt at the corner of her lips - to extend the same comparison, as faint as the fragrance of February violets - that denied, very 
subtly but quite unmistakably, her apparent total obeisance to the great god Man.

In direct contrast to Sarah's lancing looks, Ernestina's "minute tilt at the corner of her eyelids" is deliberately playful, with a more demure overall effect (188). When Sarah looks directly at Charles he interprets this as a "presumption of intellectual equality" (183). In contrast, Ernestina's indirect glances communicate her subservience. Ernestina is "sentimental as opposed to passionate" and the sentimentality of the phrase "as faint as the fragrance of February violets" indicates that it is focalised through Ernestina in a pastiche of romance novels that teach on elevated femininity (Olshen 73).

However, the line "the great god Man" highlights a valid existential concern of the novel (27). Marais summarises that "several commentators, including Jeff Rackham, William J. Palmer, Dwight Eddins, Elizabeth D. Rankin, and . . Richard P. Lynch . . . agree that this author premises his fiction on 'abandonment,' Jean-Paul Sartre's Heideggerian argument 'that God does not exist, and that we must bear the full consequences of that assertion"” (244). Roland Binns suggests that the guiding principle of Fowles's first three novels is to achieve "existentially-conscious individuals ... [with] critical awareness of the charade of received ideas (Binns 27). With this in mind, "the great god Man" could be reasonably treated as a sarcastic joke, and the capitalisation of 'Man', as though he is a God, as an acknowledgement of the "charade" of received social systems and at the positioning of a particular type of man in the highest rank (Binns 27). It also relates to the meaninglessness of Ernestina's social rank: both as an inferior and superior. Thus, the tragedy of Ernestina is that she works towards a meaningless goal that is not enough to hold Charles to his agreement.

The narrator describes how Ernestina appears to have a choice when he states that the novel occurs around the same time that "John Stuart Mill had seized an opportunity . . . to argue that now was the time to give women equal rights to the ballet-box" (115). It goes on to say that despite this failure, "March $30^{\text {th }}, 1867$, is the point from which we can date the beginning of feminine emancipation in England; and Ernestina, who had giggled at the previous week's Punch when Charles showed it to her, cannot be completely exonerated" (115, original italics). The irony in such an explanation is that if Ernestina is conditioned out of individuality, then she never has the opportunity to seek equal rights.

Landrum explains that "Charles and Ernestina are each connected with a servant specific to their sex, socially inferior, and separated by the barriers of education, language (both Sam and Mary speak in dialect), money, manners, sexual mores, privilege-all the 
indexes of social stratification" (104). In a contrast with Mary, it becomes clearer how confined Ernestina is by her education and even her social position. The narrator feels that "[o]f the three young women who pass through these pages Mary was, in my opinion, by far the prettiest" (75). The other two women are Ernestina and Sarah, but this subjective interjection on beauty is notable as it implies that Mary's beauty is in a form that transcends history. Even though Ernestina is of the mercantile class that is achieving economic advancements, it is the lower class Mary who gains some freedom from her position. In particular, "Mary is . . sexually free in contrast to Ernestina's sexual repression: the former was dismissed from Mrs. Poulteney's for kissing a groom there and becomes sexually involved with Sam not too long after they meet" (Landrum 107). This is a key point of contrast because Ernestina's infantilisation and subsequent desexualisation is an ultimate form of possession by her society. While undressing in her room Ernestina stands "before her mirror in her chemise and petticoats" (29).

For a few moments she became lost in a highly narcissistic self-contemplation. Her neck and shoulders did her face justice; she was really very pretty, one of the prettiest girls she knew. And as if to prove it she raised her arms and unloosed her hair, a thing she knew to be vaguely sinful... She imagined herself for a truly sinful moment as someone wicked - a dancer, an actress. (29)

Ernestina dresses quickly because of the "sexual thought" that crosses her mind (29). Her idea of sex is one of "pain and brutality", an animalistic act (29). Ernestina suppresses thoughts about her body and fears intercourse after marriage due to her "profound ignorance of the reality of copulation" (29). Kathleen Renk argues that "Fowles merely suggests eroticism, particularly as it relates to women" (579). Noting that this "would have been in keeping with Victorian conventions that prohibited sexual feeling among middle-class women", she further argues that Fowles makes an "effort to leave more to the imagination" (579). These arguments overlook the reason why Ernestina suppresses her sexuality, and thoughts about the sexual duties involved in marriage. To suggest this is a stylistic choice on Fowles's part drastically denies the cultivated detachment Ernestina has from her body. Sex is not left to the imagination to more accurately reflect the Victorian era. It highlights Ernestina's possession by both Charles and her society. 


\section{Sarah Woodruff}

In this section I will address some of the critical contentions made about Sarah Woodruff. Sarah is commonly read in two conflicting ways: she is either a feminist heroine, or a male fantasy void of depth. Pamela Cooper argues that the male in Fowles's fiction must "signify his power by confining the women who inspire him to the passive, mutually reinforcing roles of muse and model" (16). Woodcock laments that women in Fowles's work are "seen in relation to the male" (15). Lenz echoes this when she is frustrated by the "fragmented masculine visions always focused on Sarah as an object of analysis [because this falls] . . s short of the complete picture presumably accessible only to Fowles" (101-2). Lenz conflates the narrator with Fowles and treats Sarah as though she exists beyond the page in Fowles's possession. Sarah is a polarising figure because these points can be used to argue for the exact opposite. I argue that the fragmentary nature of Sarah is not a masculine driven oppression, it deliberately highlights the different ways a woman can be oppressed in society. It is also through her status as an 'other' that Sarah can inhabit any role, and one possessor cannot reduce and possess her because of this. Sarah's construction "challenges her fellow characters and readers alike to contemplate her consciousness, particularly in order to comprehend her generally incomprehensible actions" (Lenz 101). The interesting predicament of Sarah is that as scholars we engage the same role as the other characters in the novel: "Who is Sarah? Out of what shadows does she come?" (Fowles 94).

Dodson claims that the title of the novel is "misleading" (149). To support this, she quotes Simon Loveday who says "in the field of literature a character who develops will always steal the show ... Sarah cannot hold the place of importance ... she is merely the means. It is Charles who is the end" (71). This implies that the title should have been related to Charles. Loveday also claims that "Sarah was not the heroine . . in quite the sense that Charles was the hero" (71). These arguments are predicated on the assumption that Sarah must fulfil their definition of heroine in order to have earned the title of the novel. In contrast, Olshen reads the title in relation to Fowles's first two novels because the "character manifesting the most power" holds the title of the novel (87). In TFLW"Sarah is as much the mover of the action here as Clegg is in The Collector and Conchis in The Magus" (87). What is overlooked by Dodson and Loveday is that the title of the novel is the role Sarah willingly inhabits to forgo "the fate of many thousands of women who, especially if they did not marry, were doomed to lives of servitude and humiliation" (Barber and Messer 225). Sarah chooses to exist outside of the social norm. Thus, the title represents not only the character with the 
most power, but also reflects the possessive nature of this reduction of Sarah in the novel, one that she redefines to her advantage.

In Lyme Regis "Sarah cannot occupy a position ... [as a ] virginal white . . [ [woman] like Ernestina. Instead, she occupies the marginal, exotic, and dangerous space of the scarlet woman" (Lenz 111). Sarah's emancipation from social norms is reflected in her physical appearance, which contrasts with Ernestina's conventionally pretty face. Sarah's face "was not a pretty face, like Ernestina's . . . But it was an unforgettable face" (10). Her eyebrows are not the "delicate, fragile, arched eyebrows [of the fashion at the time, but] . . were strong ... and gave her a faintly tomboyish air on occasion" (119). The narrator notes that in the period prior to the novel's setting there had been "a great emancipation in women's fashions . .. The first artificial aids to a well-shaped bosom had begun to be commonly worn; eyelashes and eyebrows were painted, lips salved, hair "dusted" and tinted ... and by most fashionable women, not just those of the demi-monde" (168). Importantly, "with Sarah there was none of all this" (168). Enforcing particular standards of beauty on women is a way to repress their individuality. Sarah is meant to represent a freedom beyond this. She is not confined by an appearance imposed on her, which her facial features and fashion choices represent. In addition, her conduct further implies a relinquishing of gender norms. From a distance Charles first thought Sarah was "a fisherman" because she wore "a black coat . . . more like a man's riding-coat than any woman's coat" (8-9). Charles later remarks that the "coat's high collar and cut, especially from the back, was masculine - it gave her a touch of the air of a girl coachman, a female soldier - a touch only, and which the hair effortlessly contradicted" (168). At one of their secret meetings, when she walked ahead of him, Charles "glimpsed the white-ribboned bottoms of her pantalettes, which came down to just above her ankles; a lady would have mounted behind, not ahead of him" (166). When the wind strengthens Charles has to put his arm around Ernestina's waist to support her (10), but Sarah walks ahead and has to wait for him "to catch up" (167). When they walk by a cliff edge "Sarah passed quietly on and over, as if unaware of the danger", while if Charles had been alone he "might have hesitated" (167). Woodcock says that Fowles has always recognised the issue of "male power and control - the power of men over women, and the control of patriarchal social forms over the identities of both" (8). Sarah's masculine presence is an inversion and freedom from traditional power structures. Not only is she not confined by popular forms of fashion, but she, at times, takes on a masculine role in the relationship with Charles. I suggest that this represents a wholeness to Sarah that a possessor does not have. Sarah does not need 
to marry and be possessed by another because she encapsulates both feminine and masculine traits. Through this, she takes on the traditional male role as her own leader and protector.

The narrator says that Sarah "was born with a computer in her heart . . . She could sense the pretensions of a hollow argument, a false scholarship, a biased logic when she came across them; but she also saw through people in subtler ways" (53). This enables her to see through the constructed nature of behaviour, such as the social norms that dictate lives and the possessive intentions of others. Furthermore, she views "those around her as fictional characters, and makes[] poetic judgments on them" (54). This shows both an innate and learned capability for understanding others. This is a skill that all other characters in the novel struggle to attain. Her silence is about adaptability. To Mrs Poulteney she is an "object of charity" and Mrs Poulteney sees in Sarah what she wishes (33). While conversing with Sarah Mrs Poulteney suspects she may have "been the subject of sarcasm" when Sarah comments "Yes. I am to walk in the path of righteousness" (93). Sarah is not without personality, and this is certainly a sarcastic line, but when Mrs Poulteney sees that "Sarah's eyes were solemnly down, as if she had been pronouncing sentence on herself; and righteousness were synonymous with suffering", she moves on (93). Sarah invents identities for herself and plays on the knowledge that others will see what they want. To Charles she is his love interest, and then his femme fatale when she denies his proposal. To Dr Grogan Sarah is "Poor Tragedy" (154). Dr Grogan diagnoses Sarah as being "addicted to melancholia as one becomes addicted to opium", "she is possessed" (157). Dr Grogan attempts to remove Sarah's agency, he claims her actions as his own when he defines them by the science of his world. Indeed, Sarah is all of these and none of these. Sarah lives freely by using these versions of herself to her own ends.

Charles is under the illusion that he has "possessed her" after they have sex, but Sarah cannot be sexually possessed when the interaction was reciprocal (358). It was Sarah who seduced Charles and willingly entered the sexual relationship. Rosemary Laughlin argues that "Sarah is obsessed by possession ... Once she is sure of her possession of Charles in the sexual consummation of his passion, she discards him by disappearing” (86). Laughlin's argument favours Charles, whose "tragedy is that he pierces that mystery so late and perceives that she lives to practice power, by that to possess another for the sake of possession" (85). This requires that we read Sarah as obsessed by power, but she is not a possessor. Sarah does not want to reduce others to her image, her "struggle for self-respect and a meaningful role outside those sanctioned by a patriarchal society reflects the incipient struggle of the women's emancipation movement from the late nineteenth century through 
our own day" (Barber and Messer 225-6). Fowles constructs a character who seeks to find freedom through the ways society continues to reduce her.

When Sarah leaves Lyme Regis she “ceas[es] to be an object of Mrs. Poulteney's charity ... [and] an object of gossip" (Docherty 123). She is found living with Dante Rossetti in creative freedom, “'baptising' herself 'Sarah Roughwood”" (Docherty 123). Sarah no longer inhabits a name she was given by others, but a name that she has given herself. In doing so, she takes ownership of her identity. Charles had thought that he would "raise her from penury, from some crabbed post in a crabbed house. In full armor, ready to slay the dragon" (448), but as Sarah remarks she is "far stronger than any man may easily imagine" (359). Sarah is a woman of positive "self-knowledge and self-possession", living a fulfilling existence with her child (Fowles 454). 


\section{Chapter Four: Possession: A Romance}

At the centre of Possession is the discovery of an extramarital affair between the Victorian poets Lord Randolph Henry Ash and Christabel LaMotte. After the modern-day $\mathrm{PhD}$ graduate Roland Mitchell finds a draft of an unaddressed letter in one of Ash's books in the London library, he undertakes a quest to uncover its origins. He enlists the help of Dr. Maud Bailey, a specialist on LaMotte. We come to learn that Maud is descended from Ash and LaMotte's illegitimate child, making her the poet's heir. Throughout the novel we encounter an array of secondary characters. This includes the Victorians Ellen Ash (Ash's wife) and Blanche Glover (an artist and initially thought to be Christabel's female lover), and the modern-day characters James Blackadder (a scholar working on Ash, and Roland's superior), Beatrice Nest (a scholar editing Ellen Ash's journal), Leonora Stern (American, feminist scholar and specialist on LaMotte), Mortimer Cropper (American scholar and collector of Ash), Fergus Wolff (Roland's academic rival, and past lover of Maud), and Val (Roland's girlfriend).

The novel is a literary feat. It shifts between the 1980s and the Victorian era and encompasses prose, biography, diary entries, letters, academic pieces, and Victorian-style poetry, all written by Byatt. Confronting its 511 pages of narrative expanse has required scholars to circumvent much of the material. I too encountered this issue, but it seems that most others do not utilise the different, generous possibilities for critical inquiry. Despite moments of original thought, scholars consistently employ the fashionable discourse that dissects the "relationship between the present and the historical past" (Holmes, "Historical Imagination" 319) and "invariably cite parallels between the Victorian and (post)- modern pairs of lovers" (Hennelly 448).

The two love plots are clearly paralleled and both sets of lovers struggle against what it means to be possessed by another. In a letter to LaMotte, Ash writes "I speak to you as I might speak to all those who most possess my thoughts . . . and find myself unpardonably lending you, who are alive, my voice" (177). Ash desires "to possess" LaMotte, but she has no such desire to be possessed nor to possess (301). In this way, she resembles Sarah Woodruff. The relationship stifles LaMotte, and her "refusal to either contact Ash or tell him about their child, and her retreat into her pain and pride, is figured in the novel as a rejection of mutual possession, in favour of self-possession" (Mitchell, History 110). Their romance "is revised in terms of male domination and female subjugation" because LaMotte is not free from Ash by choosing self-exile (Mitchell, History 109). She becomes oppressed by the 
ramifications of their relationship, particularly Blanche's death, and surrendering of her daughter. LaMotte does not even possess her child, nor is she possessed by the title of 'mother'. Although she admits that she did not tell Ash of Maia for fear he would take her when "she was mine, I bore her - " (543), it is her sister who "brought her up as her own" (543). It is revealed that in doing this LaMotte relinquished her daughter's love because Maia misreads Christabel's concern as "something unnatural" (544). Her "most natural" instinct as a mother is distorted against her (544).

When Roland and Maud consummate their sexual relationship, Roland is described as taking "possession" of Maud "so that there seemed to be no boundaries" (507). Through their journey, Maud rewrites "the fairytale . . to include the agency of the female in giving the prince the means to reach her" (Mitchell, History 112). When she reveals her unwrapped hair it signals "her willingness to allow him to reach her emotionally" (Mitchell 112). Part of the lesson Maud must learn is that submitting sexually and emotionally will not stifle her. She must abandon self-possession and not repeat the mistakes of her ancestor. Through his freedom from Ash and possession by the letters Roland becomes creatively free: "desperately ... He wrote ... He wrote" (431). Ultimately, the novel advocates for a "conversational exchange" between past and present (Wells, "Corso, ricorso" 677). Lynn Wells argues that Roland and Maud are the most successful academics "in their interpretive projects ... [because they are able] to think of themselves and the past as participants in a dialogue or 'conversation' ([Byatt] 127)", which is carried through to their personal successes ("Corso, ricorso" 677). The two relationships are also read in terms of their "mutual possession[s]", although one couple is left unfulfilled while the other is able to rectify the poets' loses (Mitchell, History 10). Interestingly, full knowledge of the poets is never attained and the final image of the novel is of a man who has at least one moment that has not been dissected by others. All of the scholars assume that Ash never knew of his daughter's fate because there is no lasting evidence of this in their possession. The postscript reveals he did meet Maia, alone, while she was playing in a field: "I think I know your mother. You have a true look of your mother" (509).

Unsurprisingly given the title of the novel, many readings have considered possession to be a fundamental theme. However, in this chapter, I shift away from the four lead characters to show how we can explore other avenues of the novel. Establishing a foundation for readings of possession in the novel, Helen Wilkinson and Kate Limond examine collecting in the novel. Limond notes that collecting, "especially for certain characters in Byatt's fiction, is interwoven with the collector's sense of identity", which has traditionally 
been viewed as a negative trait (56). Along with Byatt's work, both John Su and Wilkinson cite “John Fowles's The Collector ... [ [for its] negative psychosexual central theme" (Limond 57). Mortimer Cropper fulfils this villainous collector role, which in Possession relates to his "preservation of the texts as objects of the past, rather than documents" (Hadley 128, original italics). Like Charles Smithson, Cropper's collecting originates from his family history. The Croppers' familial success is embedded in the family collection of "museum-pieces of the most excellent quality" (99). In childhood, Cropper was obsessed by a "collection of portrait sketches and signed photographs of eminent nineteenth- century figures" who acted as his "companions" (100). He describes how his "imagination animated their solemn features", highlighting his manipulation of the object to both control and fulfil a possible loneliness (100). Cropper's possessive desire for Randolph Ash derives from a letter Ash wrote to his "great-grandmother, Priscilla Penn Cropper" (101). He is obsessed with "documenting every last item of the days of Randolph Henry Ash" (99), and is "in the habit of drawing Randolph Henry Ash's large gold watch from an inner fob pocket, and arranging his time by Ash's timepiece" (23). Collectors such as this imbue in the objects their life's purpose. For Cropper, collecting is "central to his identity" (Limond 58). He has "no separate existence" (105) from his "life's absorbing interest" (Byatt 102) "to possess all of . . . [Ash's] remains and bring them together in a single collection" (Hadley 128, original italics).

The novel illustrates a debate over cultural rights to a literary figure. Blackadder loathes Cropper partly based on the belief that "British writing should stay in Britain and be studied by the British" (10). The letters may "vanish, into America" if Cropper were to access them (91). It also juxtaposes an exhaustive American- capitalist style consumption of the object with the British scholars' supposed "standards of taste [and] preservation of culture" (Olmstead 291). American collectors are often thought of as "not only possessors, but possessed" (Olmstead 291). Cropper is followed by rumours of possible thefts he has committed during his hunt for collectible items (483-4). It is Cropper who goes to the most depraved lengths to access a final letter the scholars know to be buried with Ash. However, the moral contrast between the American and the British is only black and white on a reductive level. Roland uses the word possessed multiple times to justify his theft of Ash's letter from the London library - "I felt possessed. I had to know" (486). Roland and Maud both justify their desires: 'I feel so possessive about the damned things. They're not mine.' 'It's because we found them. And because - because they're private"' (91, original italics). Furthermore, while Cropper is punished for his grave-robbing, the other scholars benefit from 
his possessive drive by resolving the love affair and discovering Maud's ancestry through the letter.

In my research it was pertinent to first establish Cropper's relationship to the material to then develop a reading of the forms of possession in the novel. The other characters, though not the antagonists, often behave in ways similar to Cropper. In contrast, they predominantly use interpretation and assumption to construct their subjects' identities, and in turn their own. Kate Mitchell draws on the theme of possession when she explains that the novel treats the "literary text as a medium for cultural memory" (94), but as noted by Louisa Hadley, "[r]eading does not always have such positive effects ... there are readings that seek to possess the past and in doing so deny it an afterlife in the present" (123). What is particularly interesting about Mitchell's approach is her recognition that "an ideal reader who is willing not only to possess the text, but also to be possessed by it . . . is [in] a relationship not of ownership ... [but] a relationship of desire" (94). In this way, "[t]he novel exploits the multiple meanings of the term 'possession' ... [it has an] active form 'possessing', which is implicated in the approach of Byatt's literary academics, whose attempts at appropriation bleed the text of its vitality. It also refers to the more passive state of 'being possessed' and implies a relinquishing of authority and ownership" (Mitchell, History 100). Thus, the role of possession in the novel is far more complex than a binary between positive (not possessed) and negative (possessed), which we see in The Collector and The Game. In this novel, possession can be a part of a mutual exchange and can initiate freedom. This chapter will now be divided into sections on the characters Beatrice Nest and Ellen Ash, James Blackadder, Leonora Stern, and Val and Blanche Glover.

\section{Beatrice Nest and Ellen Ash's diary}

Beatrice and Ellen are closely intertwined in the novel as subject and object; an examination of one lends itself to scrutiny of the other. Beatrice is characterised by images of loneliness and confinement, but unlike Cropper's descent into depraved measures, Beatrice's possession becomes positive.

Beatrice's objects are Ellen Ash's writings and Ellen Ash. Beatrice is introduced as a character mentally and physically confined by this focus. Beatrice is "almost bricked in by the boxes containing the diary and correspondence of Ellen Ash" (27). The bricking in, which emphasises the physicality of her oppression, resonates with gradual entrapment. Unable to escape the writing, Beatrice is slowly becoming contained by it. Furthermore, because 
Beatrice perceives that things are "omitted" (221) from Ellen's writing, it creates layers of interpretation that entrap Beatrice in a "web of categories" (118). George Poulet describes texts as "objects [that] ... wait for someone to come and deliver them from their materiality, from their immobility" (41). Poulet's personification of the text reflects the traditional relationship between reader and text, which is that the text requires a reader for its contents to have meaning. This places the reader in the dominant position of control to initiate a "conversational exchange" (Wells 677). The completion of Beatrice's study of Ellen is pending, She is partly unsuccessful as an academic because she is trapped by the texts. Rather than delivering the texts from their materiality by engaging with them on a mutual basis, the objects are in the position of dominance over her.

When she came to studying Ellen, Beatrice initially had "a period of clear observation and detached personal judgment" (115). Her "immers[ion] in her subject" meant she "began to share Ellen's long days of prostration in darkened rooms" and became enslaved to a woman who refuses to be read in obvious ways through her diary (115). Beatrice sees herself as Ellen's protector, but there is an air of possession to her desire to keep Ellen to herself. When Roland wishes to view Ellen's diary Beatrice will not allow him to see them, only checking her own card indexes. After some pleading, Beatrice finally agrees to let Roland read the diary, but he has to "sit opposite" her to do it (119). This is both possessive and protective, and Beatrice remains in this state for most of the text, feeling that Ellen "shouldn't be-exposed" (235). What becomes clear is that Ellen does not allow herself to be exposed through her writings, regardless.

This is not the only way Beatrice is confined. As a young scholar she had wanted to write her PhD dissertation on Randolph Ash's “poem-cycle, Ask to Embla” (13, original italics). Instead, Beatrice's supervisor, Professor Bengtsson, assigns her what he deems is the more gender-suitable task of editing Ellen Ash's diary and letters (114). Beatrice is implanted in a gendered hierarchy that mirrors the genre of writing she studies: women's diaries. According to Adrienne Shiffman, women's diaries and journals have been called "the inadequate female text" (96). Furthermore, "the dominant discourse . . . devalues the female diary as a literary form" (96). Yet, the diary "form was fundamentally suited to the day-today time parcelled fragmentation of women's lives" (Brindle 55). Unlike Ernestina Freeman who "attempt[s] to call upon diary support to beseech her errant and escaping fiancé", for some it existed as a medium through which to exert control over the self in one of the forms that was theirs (Brindle 54). And yet, the writing they were able to produce is devalued. Ellen is the wife of a great poet, the purpose of studying her is supplementary to study of him. To 
force Beatrice to study Ellen deems Ellen as less than Ash, and Beatrice as less than the men who study Ash.

Other scholars have taken issue with this devaluation. Shiffman explains Luce Irigaray's view that "female sexuality has been conceptualized on the basis of masculine definitions, and, consequently, women exist in a simultaneous state of 'lack' and 'desire'; women do not have but desperately want the male penis, the only sexual organ of recognized value in a phallocentric system" (100-1). Shiffman argues that when Ellen refuses to consummate her marriage she "disrupts this phallocentric order ... Her 'hole' is a 'whole': it is presence not absence, power not powerlessness, meaning not nonmeaning . . her vagina . . . is a site of subversion of the dominant patriarchal discourse" (101). Yet, does this really explain the significance of their mariage blanc? When Shiffman, writing in 2001, applies Irigaray's reading of female sexuality to the novel she channels a dated phallocentric discourse. Byatt even parodies this kind of feminist reading when Leonora asks: "what surfaces of the earth do we women choose to celebrate who have appeared typically in phallocentric texts as a penetrable hole, inviting or abhorrent, surrounded by, fringed with some-thing?” (244). Shiffman's analysis of Ellen's virginity unintentionally denies women sexual autonomy by suggesting that, while Ellen's vagina may not be a site lacking and in need of male dominance, it is also not a site for her own sexual pleasure. This unnecessarily denies Ellen's contextual oppression. Indeed, Ernestina and Ellen are similar in this way. On the one hand, Ernestina cowered from her naked body, but Ellen recalls her naked image with fondness, the small "high breasts, with warm brown circles. A skin like ivory and long hair like silk. A princess" (460). On the other, Ernestina's animalistic and brutal vision of sex, due to a "profound ignorance of the reality of copulation", correlates with Ellen's experience (Fowles 29). Ellen remembers Ash's "naked male, curly hairs and shining wet, at once bovine and dolphin-like, its scent feral and overwhelming", herself denying his touch at every attempt, finally giving in and feeling " $[\mathrm{t}]$ endons like steel, teeth in pain, clenched, clenched" (459). It is in Ash's acceptance of their abstinence that Ellen "became his slave" (459). We can acknowledge Ellen's power in the novel through her diary, and in relation Beatrice's, without denying her sexual oppression in a society that cultivated women's naivety.

In Epistolary Encounters in Neo-Victorian Fiction Kym Brindle draws from a number of resources when she discusses Ellen Ash. According to Brindle, "Gerald Prince asks us to consider why the narrator begins keeping a diary in order that we may understand the diarist" (58, original italics). Brindle notes that Maud asks this question of Ellen: 
[']What I want to ask is - why did Ellen write her journal? Was it to please her husband?'

'Oh no.'

'Did she show it to him?'

'Oh no. I don't think so. She never says so.'

'Do you think she wrote it for publication, in any form?'

'That's a harder question. I think she knew it might be read[']. (219)

Brindle argues that "Beatrice's explanation is at odds with Lorna Martern's understanding that diary novels function to provide a 'single first-person narrator who does not address himself to the fictive addressee or recipient"” (54). The diary can be divided "into two sub-genres: the "truly private diary' and the "public private diary"' because the "suggestion of [an] external readership entails the possibility of self-censorship" (Shiffman 94). The diary has a veneer of personal correspondence with the self, but the assumption that it will become public entails self-censorship. This retains a distance between 'the real' Ellen and the one presented in her diary. She employs the implied author. Byatt utilises the "diary form to voice marginal characters", including "Ellen Ash, Blanche Glover, and Sabine de Kercoz" (Brindle 53). Ellen plays with the "anticipation[] [of] an external audience" (Shiffman 101). In Mortimer Cropper's “The Great Ventriloquist” he relays that "Ellen laid upon it [the coffin] a box, containing 'our letters and other mementoes' which were 'too dear to burn, too precious ever to expose to the public view"' (443, original italics). The quotes from Ellen's journal are recognised by Beatrice as intending to entice, "she leads you on and baffles you ... She wants you to know and not to know. She took care to write down that the box was there. And she buried it" (485). Even when we assume that unfiltered access to a mind and a life is available through a diary because it occupies a more private literary space, Ellen "self-consciously constructs her journal as 'bait' for the 'vultures' and 'ghouls,' knowing that they will most certainly dig up her own letters to Randolph and, in turn, discover Christabel's. So, in addition to Christabel, each of the scholarly 'vultures'Blackadder, Cropper, Maud, Beatrice, Leonora, Roland-remains entirely in Ellen's hands" (Shiffman 102). In this way, Byatt repositions the importance of the diary, women's creativity, and the female scholars who study them. As Brindle suggests,

LaMotte delivers herself to Ash, textually and bodily, while Ellen's diary is more a lost letter to herself. Ash's and LaMotte's shared secrets and bodily communion 
become interrelated in their poetry and letters. But Ellen's chaste flesh denies exchange and results in textual secrets that are suspended in her diary awaiting later for whom text will suffice in the absence of body. (55)

Ash and LaMotte through "the association of letters with secrets and seduction ... signifies the surrender of Possession to its subtitle, A Romance", but Ellen's creative autonomy and control becomes the means forward for the scholars in the novel (Brindle 36). There is a clear transition from the possessed female creativity in The Game to showing the boundlessness of women's writing, particularly diaries, in Possession.

\section{Foreshadowing and Transformation of Beatrice Nest}

The allusion to Dante's Divine Comedy foreshadows Beatrice's transformation and creates an undercurrent of power beneath the male perspectives of Beatrice and Ellen. The narrator relays that when Roland first arrived to study he likened the British Museum to "Dante's Paradiso, in which the saints and patriarchs and virgins sat in orderly ranks in a circular formation", and "the Ash factory, hutched in the bowels of the building, was the Inferno" (26). In Dante's Divine Comedy "The Inferno" is the section that follows Dante through Hell. We are first told that Roland works "in what was known as Blackadder's Ash Factory", although Roland is "essentially unemployed, scraping a living on part-time tutoring, dogsbodying for Blackadder" (10-1). Thus, with Blackadder as its head, for Roland the Ash Factory represents a scholarly hell where he exists in academic limbo. Peter Bixby argues that the second line shows a shift to an "externally focalized vision", but I argue that the focalisation remains with Roland, indicated by the first unflattering descriptions of Blackadder and Beatrice (160). There are two important aspects to the intertextual references to Dante. Firstly, in Canto 32 Dante writes:

The wound that Mary closed and anointed, that soul so beautiful at her feet is she who opened and inflicted it.

Below her, in the third tier of seats, sits Rachel with Beatrice, as you see.

Sarah and Rebecca, Judith, and her who was

great-grandmother to the singer who, grieving at his sin, said: ' Miserere mei ,' 
you can see, following each other down tier

by tier, as I with the name of each go from petal

down to petal in the rose. $(1-10)$

While Roland references the hierarchy of "saints and patriarchs and virgins" in relation to the reading room at the British Museum, we can draw inferences about how this relates to the hierarchy in the Ash Factory (26). Blackadder is at its head, followed by "his clerical assistant ... Paola" (27). Beatrice is relegated to "an inner room, beyond the typewriter cubicle, ... [in] a small cavern constructed of filing cabinets" (27). Andrea Rohland-Le argues that Beatrice “is ironically unlike her Italian namesake, Dante's beloved, having loved no man and been loved by no one in return" (105). This is true at least with how Beatrice is constructed for most of the text. Where Dante's Beatrice ranked with the virgins a tier below the Virgin Mary, but above the patriarchs and angels, Byatt's Beatrice is a lowranking scholar in both externally and internally- induced isolation. Where my argument differs is that the reference to Dante foreshadows Ellen's and Beatrice's eventual authority. In "Paradiso" Beatrice guides Dante through Heaven. In Possession Beatrice plays a key role in Maud and Roland's ability to follow the Ash and LaMotte correspondence, both as herself and as a possessed figure. Beatrice supplies Maud with copies of a letter Ellen received from Blanche Glover. In addition, Ellen's diary becomes a key to unlocking the mystery of Ash and LaMotte as details in Ellen's diary lead them to the graveyard. With Beatrice established as the living protector of Ellen, she also becomes an assertive authorial presence. Beatrice is first an enslaved protector, but is then aroused as the living embodiment of Ellen. From the "grotesquely swollen", impregnated imagery of Beatrice when she imagines herself "with Ellen Ash" like a "living weight", Ellen's possession of Beatrice becomes a form of rebirth (130). The bowels of hell in the Ash Factory become a womb of sorts, where the conclusion of the mystery grows from Ellen through Beatrice.

When Beatrice calls for Maud she introduces herself as "Beatrice Nest. On behalf of Ellen Ash. No, not exactly on behalf-except that I do feel-I do feel-that it is for her that I am-" (438). She is determined that Mortimer Cropper should be "stopped from disturbing their rest" (485). What these examples imply is that Beatrice is not simply working on behalf of Ellen, she is working with Ellen, finally achieving mutual exchange through possession. When Mortimer Cropper digs up Ash's grave to retrieve the box he "spun round, and the beam of the other's flashlight revealed, peering through the branches, like bizarre flowers or fruit, wet and white, Roland Mitchell, Maud Bailey, Leonora Stern, James Blackadder, and 
with streaming white woolly hair descended, like some witch or prophetess, a transfigured Beatrice Nest" (496). The power of this image suggests the transformation of Beatrice. Like an ethereal prophetess, Beatrice is fully possessed by Ellen, invoking the power of two women who now exist as one. This also calls to mind Christabel who wrote "Am I a Sorcerer-like Macbeth's witches - mixing truth and lies in incandescent shape" (168). As it transpires, Ellen is more the sorcerer, mixing truth and lies in her journal. While Ellen was inaccessible, Beatrice is able to present a physical manifestation of her as a presence in the graveyard, attempting to protect her husband.

Jane Campbell suggests that "Beatrice attains real understanding of her subject. With surprising decisiveness, she acts 'on behalf of"' (127). I argue that this is more than Beatrice coming to understand Ellen. The novel suggests an interesting point for consideration: that there is value in possession, that a possession can shift from being negative and confining, to allowing for freedom. When Maud looks at the photograph of her "great-great-greatgrandmother" Beatrice cries (503). Maud turns to Beatrice for insight - "You know Ellen" asking her why Ellen would have put the letter "in the box - with her own letters" (503). Beatrice says “[s]he didn't know what to do, perhaps. She didn't give it to him, and she didn't read it - I can imagine that - she just put it away" (503). Ellen did not have power in her lifetime, but Beatrice's physical response and her expression that Ellen did not know what to do seems to suggest regret on her behalf.

The reference to Dante foreshadowed the relevance Beatrice and Ellen were to have. When they were seen through men's perspectives they were less than them, and yet, they both become important figures in achieving the conclusion of the love affair. They begin with what a society of men has given them to become something stronger.

\section{Introduction and suppression of James Blackadder}

James Blackadder is usually only briefly mentioned in critical accounts of the novel, and in relation to Roland. This is somewhat surprising as he demonstrates different ways of being negatively possessed, but is able to attain freedom and distance through his own authority. At the beginning of the novel, Blackadder lacks freedom outside of his object: Randolph Ash. From a young age, Blackadder faced familial pressure to study Ash. His grandfather "recited poetry", including Ash's Ragnarôk, and "his father sent him to Downing College in Cambridge to study under F. R. Leavis", a real- world literary scholar who Byatt uses as the authority on Ash at this time (27). Spiritual possession permeates the novel, but 
Blackadder's is the first instance of possession by a daemonic familial spirit: his grandfather. This calls to mind Byatt's introduction where she writes that her initial intent was that the novel "would be a kind of daemonic tale of haunting". The use of daemonic instead of demonic is significant as daemonic means "an inner or attendant spirit, esp. as a source of creative inspiration or genius", and demonic means "of or relating to demons or a demon" ("demonic"). Blackadder's grandfather embeds a possessive weight on him in his youth so that he feels he came "to editing Ash out of pique" (27). The narrator recalls the moment Blackadder's "fate was decided" (27). In a seminar where Leavis led students into misdating the chosen pieces in order to "demonstrate his own analytic brilliance", Blackadder, "schooled by his grandfather", realised that the texts were by Ash (28). Given the choice to "state his knowledge, or to allow the seminar to proceed" he stayed silent (28). This contributes to a guilt that becomes a part of Blackadder's later commitment to studying Ash. He feels he "had somehow betrayed Randolph Henry Ash" in this seminar (28). A moment of subjective input from the narrator suggests the nuances of Blackadder's guilt: "he might more justly have been thought to have betrayed himself, his grandfather, or possibly Dr Leavis" (28). To compensate for this presumed betrayal of Ash he chooses him as his $\mathrm{PhD}$ subject, and becomes an expert on his work (28). Even if Blackadder is unable to recognise it, his grandfather speaks through him in powerful but stifling ways so that his feelings of guilt after the seminar are in relation to Ash, his family, and by extension to himself.

Byatt also draws our attention to Leavis's possession of Blackadder who first suppresses, and then overtakes him. Leavis is described as having deprived Blackadder "of any confidence in his own capacity to contribute to or change" English literature (27). Ann Marie Adams argues that Blackadder is "caught up in his own constraints of rigid scholarship and creatively crippled by the critical legacy of F. R. Leavis" (110). This is certainly the case, and he is also crippled by a lack of confidence implanted during his time as a student. This resulted in Blackadder burning his poems after imagining "Dr Leavis's comments on them" (27). By first suppressing and then imposing his ideals, Leavis essentially performs the abstraction process and academically possesses Blackadder. This assumes a control over him that extends beyond Leavis's physical presence at the university. In particular, the stylistic effect of this possession of Blackadder's scholarship is noted through his development of "an essay style of Spartan brevity, equivocation and impenetrability" (27). This description suggests a lack of personality in the writing style, particularly of any subjectivity, but also of fear of vulnerability. Like Cassandra, he writes in a style that will, hopefully, shield him from critique. Blackadder edits his work thinking "superfluous adjectives were the traces of his 
own views, and therefore unnecessary ... Much of his writing met this fate. It was set down, depersonalised, and then erased. Much of his time was spent deciding whether or not to erase things. He usually did" (300). While Blackadder was deprived of his creative abilities because of Leavis, he also becomes deprived of any expression of the self in his work. Leavis suppresses and moulds Blackadder who continues to be possessed by this scholarly heavyweight into his adulthood.

\section{Similarity to Beatrice Nest}

Blackadder's scholarly and personal suppression manifests in contempt for others, which is often gendered. Blackadder resembles Beatrice as both were forced into studying their objects. Beatrice is also the main target of his scholarly disdain, although he has distaste for any female or feminist scholar. When his assistant Paola suggests that "the feminists are interested in" LaMotte he replies "they would be . . They haven't any time for Randolph Ash" (31). All they want is to read Ellen's endless journal once our friend in there has actually managed to bring it to the light of day" (31). Blackadder moves swiftly from LaMotte to Ellen in a move that bypasses and disregards LaMotte, but also categorises them as 'female writers' because feminists have taken an interest in both. Furthermore, within this context the word "friend" is sarcastic rather than personable. This interpretation is supported by the following mentions of Beatrice who is also Blackadder's target because of her association with the feminists. We are told Blackadder believes the feminists "think Randolph Ash suppressed Ellen's writing and fed off her imagination" (31), but Blackadder thinks " $[\mathrm{t}]$ hey' $\mathrm{d}$ have a hard time proving that . . . if they were interested in proof, which I'm not sure they are. They know what there is to find before they've seen it" (31). There are two forms of jealousy interplaying in these lines. The feminists do not produce work in Blackadder's objective-style, and his distaste is reflective of a negative gender hierachy. When feminists fight back against oppression men can feel attacked by this action. This manifests in Blackadder's response to the attack on Ash. Blackadder's identity from youth has become so intertwined with studying Ash that it is a form of possession by the texts. To support this reading, I refer to Blackadder's treatment of Val. When Roland's partner Val was studying under Blackadder she wrote a piece called "Male Ventriloquism", which was "judged to be good work... [but was] discounted by the examiners" because it was assumed that the piece was largely produced by Roland, which we learn is untrue (12). Furthermore, the argument in the work was that Ash "neither liked nor understood women, that his female 
speakers were constructs of his own fear and aggression, that even the poem-cycle, Ask to Embla, was the work not of love but of narcissism" (13, original italics). Who the examiners were is not said, but that the examiners knew that Roland and Val were a couple means it was likely internal, and, I would argue, there is evidence to suggest it was Blackadder when one considers his attitudes towards women in the rest of the novel. Val's grade was based on a gendered assumption that she was less capable than Roland, but also because it was an attack on Ash: another male. Val's feminist reading of the text that claimed Ash as a misogynist was, by extension, an attack on Blackadder. Thus, if Ash is viewed as misogynistic, then so is Blackadder.

Due to his repression, Blackadder must conceive his superiority over Beatrice and Ellen. He says the feminists' "real problem - and Beatrice's - is that Ellen Ash is dull" (31). At another point Blackadder claims to find "Ash fascinating" (29). With scholars possessed and inseparable from their objects, the implication of this is that Blackadder is interesting, and Beatrice is dull. Perhaps the more interesting aspect is the demeaning manner with which Blackadder speaks of Beatrice. On one page he refers to her as "Poor old Beatrice", "Poor Beatrice", and "poor old Bea" (31). This succession belittles Beatrice so that she is 'poor' and 'old', meaning she is dated and unfulfilled. The shortened and more personal 'Bea' is a nickname that would suggest intimacy if it were not for its patronising condescension. He lacks empathy for Beatrice and her "long-delayed edition of Ellen Ash" is a point of ridicule (31). According to Roland, when Blackadder talks about Beatrice his voice has "a jarring, snarling note, [like] . . hounds baying" (32). Yet, with the novel's present being 1986, Blackadder's own scholarly pursuits are also in limbo. Initially believing it would be "a finite task that would lead on to other things" (28), Blackadder has been "editing Ash's Complete Works since 1951" (3), and began Ash's “Complete Poems and Plays as early as 1959” (28). Beatrice was an undergraduate student in "1938-41", which means she has been editing Ellen for over 40 years (113). Although Blackadder has not been editing Ash for quite this length of time, Beatrice is both his reflection and his future. She is his mirror image, reminding him of his confines and scholarly inadequacies everyday; she embodies his insecurities.

This mirror image of the two characters is further supported by the description of his office. He sits "amongst the apparent chaos and actual order of his great edition, sifting a drift of small paper slips in a valley between cliffs of furred-edged index cards and bulging mottled files" (27). There are persistent descriptions of confinement in the novel, and Blackadder and Beatrice are constrained by others, their research objects, and themselves. For Blackadder, the confinement seems to call to him as though he is possessed: he "might 
yet have insisted on returning to his burrow, the tools of his trade, his typewriter, his telephone" (425). Despite taking out his frustrations on those in the Ash Factory, and his students, he craves this familiar space. At an earlier point in the novel he ruminates on the realisation that he will "end his working life ... in this task [of editing Ash], that all his thoughts would have been another man's thoughts, all his work another man's work" (29). Blackadder's realisation is that his life has not been wasted, and that even if he is subordinate to Ash "it was a pleasant subordination" (29). There is a comfort in this and an attempt to accept his situation. It is neither an entirely negative or positive sentiment, and this leads to his ability to break free, in some ways, of his possession. What he finds the most comfort in at this time is that "he believed Mortimer Cropper thought himself the lord and owner of Ash, but he, Blackadder, knew his place better" (29). For such an under-examined character, these lines call to mind the introduction where Byatt, writing in the first person, ponders the motivations of Kathleen Coburn, the great editor of Coleridge, and wonders whether "he possess[es] her, or does she possess him?”.

\section{Transformation of James Blackadder}

Blackadder attains separation from Ash by cementing himself as the authority figure on Ash, and as a scholar in his own terms, not as a scholar subordinate to his research subject. Blackadder is a leading authority on Ash throughout the novel. He is the scholar preferred by the current Lord Ash, his name is often mentioned for consultations on Ash, and he is invited to speak on a television show because the journalist "had asked around and had been told that James Blackadder was the expert to have on her programme" (339). With the novel's progress he transforms from possessed subject, to protector and authority figure, whereas Beatrice transforms from stifled protector to the embodiment of Ellen. For Blackadder to become the protector and leader, he must attain distance. We witness Blackadder's inability to see objectively at the start of the novel when Roland says "I think I've made a discovery" and Blackadder responds "[i]t will probably turn out to have been discovered twenty times already" (30). At this point he is resigned to what is already known. However, Blackadder begins to transform when he follows Roland and Maud and starts to find an identity outside of Ash.

When Blackadder starts to diverge from Cropper he is able to surpass him and thereby finds a separate existence. On the box that is laid on top of Ash's coffin Blackadder remarks "it may lie concealed forever in the grave" (428). Although this turns out to be incorrect, he 
correctly predicts that Cropper "is capable of grave robbery" (483). From here, Blackadder is placed in a role of authority over the other scholars and over Ash, whilst Cropper delves into transgressive behaviours. For example, Blackadder leads the conversation when they question Maud and Roland: "I should like to know . . . how you came across the correspondence in the first place" (480). Furthermore, Blackadder leads the group with "two, or three, final questions: "One: what became of the child, alive or dead? Two: what is Cropper trying to find out? On what basis of knowledge? And three: what became of the original letters?" (482). Where Roland and Maud make the first discoveries and lead the other scholars on a quest for the truth of the LaMotte and Ash affair, in the final moments they turn to Blackadder to lead them "to the end of the story" (498).

Cropper's financial freedom had previously allowed him access to objects of Ash's that Blackadder could not afford. Roland who had "felt possessed" by the letters hands them to Blackadder to be safely returned to the Library (486). Blackadder is "unable to resist reading them then and there, to turn the paper lovingly, possessively, recognising the writing" (482). The word 'possessively' is important as it shows that Blackadder is the one possessing the writing but in mutual exchange. Furthermore, he does not stoop to Cropper's level and steal them for a personal collection. When the academics have the box in their possession, Maud and Blackadder converse: "“[w]e need the end of the story.' 'There is no guarantee that that is what we shall find,' said Blackadder. 'But we must look,' said Maud” (498). This shows the connection between Blackadder and his role in uncovering the final layers of truth. The others turn to Blackadder for guidance, and it is he who alludes to what occurs in the postscript when he says that a conclusion to the story may never be found. At the end, Blackadder is the one to note that the quest has been to discover Maud's "origins", and that the box was preserved for Maud (503). Blackadder invokes a pseudo-narrator in place of Randolph and LaMotte. He becomes the one to inform Maud, even if she had already realised it herself. Ultimately Maud decides "these papers should go to Professor Blackadder, for safe-keeping" (504). With Maud the likely heir to the correspondence, she deems Blackadder the authority and protector of the letters.

\section{Leonora Stern}

Aside from Maud, the other specialist on LaMotte is the American feminist academic, Professor Leonora Stern. Leonora is an example of someone who denies possession by others, and instead turns to an unfettered need to be a possessor. She bears a resemblance to 
her American counterpart, Mortimer Cropper, but is led by possession of the person rather than the object. When Maud thinks of Leonora it is of her "ferocity", and the character is also known for her physical appearance (221). Described as "a majestically large woman, in all direction[s]", Leonora's physicality and personality are both imposing (336). "She dressed up to her size", and there was "a hint of Africa in the lips, and a mass of thick black, waving hair, worn shoulder-length and alive with natural oils - the sort of hair that would clump and gather in the hands, not fly apart" (310). This description suggests she appears to physically take on many ethnicities and schools of feminist thought, notably Black feminism. She wears several layered necklaces, a "silk bandeau" and claims "both Creole and native Indian ancestry. Her maiden name had been Champion, which she said was French Creole (310). Writing on feminism and fashion in an article for Vogue in 1997, Elaine Showalter says that there is a perception that after the age of 30 feminists should "aim for one of the three E's: "earthy, ethnic, or elegant'" (86). She uses Leonora as an example of "the ovarian earthmother look" (86). This view of Leonora as earth-bound extends to her scholastic presence as her analyses of LaMotte often tie the poetic imagery to the female body and then to the earth. Jessica Tiffin notes that "intellectualism and sexuality are . . to Byatt, separate rather than integrated, in sharp contrast to the Leonora Stern school of sex-in-everything" (55). Tiffin argues for the "novel's gentle ridicule of Leonora", which shows that Leonora is Byatt's feminist opposite (57). Leonora's exploits are highlighted for satirical effect, yet, I suggest that even if she represents a kind of feminism that Byatt mocks, there is also strength in Leonora's characterisation, one that sees her progress from rampant possessor, to a motherly figure who is able to renounce her possessiveness.

Leonora is an immaterial presence for much of the novel. Presented as a secondary figure through the partisan lens of other characters, she physically appears over half way through the novel. Her figuration is somewhat similar to that of the Victorian characters, who linger in the minds of those they have possessed, but who are predominantly presented through the entities of their creation. For Leonora, her characterisation is revealed through her note on the grave, and the access to her academic work on LaMotte. Aside from this, in a way she has possessed Maud, whose thoughts will linger on Leonora, and who feels the force of her even when she is not present.

On receiving a letter from Leonora, Maud feels "reluctant to open" it because it has "an imperious and accusing air" (137). Maud transfers her feelings of guilt at hiding the AshLaMotte correspondence from Leonora to the letter, but is actually reacting to the sender of the letter, not to the material object. Leonora has possessed Maud to the point of being able to 
evoke guilt by sending a letter that has yet to be read. A point of contention for the following interpretation is that Byatt has "criticized Women's Studies" (Franken 90). She has also claimed that "[Leonora's] style is revolting in the extreme" (Franken 90). My intention is not to disengage from evidence of authorial intent and opinion. Nor do I seek to only embrace Byatt when she supports my reading. Rather, this understanding of Byatt has meant that readings of Leonora are dominated by noting the ridicule, and disregard of her as a scholar. Yet, evidence in the text suggests this may not be entirely the case. There are conflicting stances on feminism portrayed through Leonora and Maud that do not allow for a simple pro/anti-feminist reading of either character. Tiffin highlights the "stereotyped feminist interpretation of water as feminine, sexual, and generative, as in Leonora's analysis", but suggests that "Byatt's actual interest in water is not in its sexually creative symbolism but in its relationship to glass and its more abstract ability to mirror and reflect the demands of art" (57). Tiffin convincingly supports the interpretation that Leonora as a scholar is being satirised, and this reading is evident when Leonora wants to look for "non-genital imagery for female sexuality" (139). Throughout the text, Maud is depicted as the more rational feministscholar, but she tries to distance herself from the feminist title. She thinks the state of LaMotte's grave is "all right. A slow return to nature and oblivion" (71). This is in sharp contrast to Leonora's emotional distress at the grave, which she tries to tidy up, angering Sir George (the owner of the property). Where Leonora heavily sexualises and craves biographical material, evident in her claim that LaMotte is "a lesbian- feminist poet" (485), Maud "very rarely feel[s] any curiosity about Christabel's life" (55). Maud feels a "sort of squeamishness about things she might have touched, or places she might have been [because] it's the language that matters ... what went on in her mind" (55). There is passivity to Maud's characterisation; she is easily manipulated and insecure. At a meeting, "the feminists . . . hissed and cat-called, assuming her crowning glory to be the seductive and marketable product of an inhumanely tested bottle" (57). In response, Maud shaves off her hair to re-legitimise herself through her appearance. How she alters her appearance reveals her insecurities. During her sexual relationship with Fergus Wolff he "divined how afraid she was of the doll-mask and had dealt with it in his own way, daring her to let it all hang out, quoting Yeats at her in his Irish voice" (57). In response to her reason for shaving it off they converse: “'You should be ashamed to believe that,' said Fergus, 'and you so wise and clever about every other thing, my dear.' 'I don't,' Maud had said, 'believe that or care. So he had dared her to grow it' (57). The image of Maud's hair being a doll-mask is evocative of the idealised female -appearance. The challenge and seduction of Maud by Wolff seems to be a 
test of not only the kind of control he has over her, but whether she will allow someone else to dictate her appearance based on their desires. Where she first shaved her hair under pressure by feminists wanting to forego mainstream beauty ideals, she then grows her hair out to please a man. Arguably, these are both antifeminist actions in our modern era.

Unlike Maud, Leonora refuses to be subjugated by any man. This makes her more similar to LaMotte than LaMotte is to Maud. We can again refer to Shiffman's references to Luce Irigaray and sexuality as "conceptualized on the basis of masculine definitions" because Leonora represents a reclamation of sexuality (100). Leonora's sexual appetite is one that attempts to possess bodies, but it is not gendered. She has "two husbands", a lover named "Mary-Lou", and attempts to seduce Maud and just about anybody she meets (315-6). Samantha Carroll argues that "set against Glover's sexual effacement, Leonora's unfettered lesbian proclivities cast her as the Victorian woman's licentious doppelgänger" (359). Whilst this is an interesting analysis, she also proposes that there is a good and dangerous dichotomy between Leonora and Glover (368). However, what the novel illustrates is that her sexual appetite is tied to a need to possess whatever is available, specifically people.

Additionally, where Maud grows her blonde hair for Wolff, Leonora refuses to be boxed in by "her first husband, Nathaniel Stern" (310). Nathaniel does not "survive Leonora [and] ... feminism", he writes a book that attracts feminist attacks, and then tries to "placate the feminists by embarking on a biography of Margaret Fuller Ossoli. Twenty years later he was still working on it, disapproved of by everyone, particularly the feminists" (311). Leonora is involved in the feminist attack on Nathaniel, but it is significant that his work is "disapproved of by everyone" (311). What was first a discord with a marginal group becomes a discord with a mass scholastic readership. By divorcing her husband, and showing sexual freedom, she refuses to be involved in his dislike of feminism. Even by taking her husband's name, she dominates this traditional symbol of ownership. She owns the name rather than having it own her.

Linguist Lynne Murphy explains that the use of 'the' before a group can make "the group seem like it's a large, uniform mass, rather than a diverse group of individuals. This is the key to 'othering:' treating people from another group as less human than one's own group". She notes that in Nazi Germany Jewish people were referred to as "die Juden ("the jews"), homosexuals have been referred to as "the gays", and the phrase "the Americans say it that way" can be used by "those who feel that American English threatens British English . .. [the use of 'the'] hold[s] Americans at arm's length". Leonora is faced with two forms of 'othering' in the text. 'The' is used before American in the text and with negative 
connotations. Cropper is referred to as "the American" (415), and someone asks "[w]ho was the American? Must be Leonora" (327). Furthermore, there is a consistent othering of feminism in the novel. Phrases include: "I think the feminists are interested in her" (31), "The feminists are crazy about it" (33), and "Thirty years later the feminists saw Christabel LaMotte as distraught and enraged" (37). The recurrence of 'the' before American and feminist confirms contempt for Leonora as an American, feminist academic.

Leonora draws on the "female-visioned female-enjoyed contours of Mother Earth", and invokes the Mother Earth persona (244). When Roland is reviewing LaMotte scholarship, Maud supplies him with Leonora's Motif and Matrix in the Poems of LaMotte" (243, original italics). Chapter headings include: "From Venus Mount to the Barren Heath"; "Female Landscapes and Unbroken Waters, Impenetrable Surfaces"; "From the Fountain of Thirst to the Armorican Ocean-Skin" (243). The vision that Roland has after reading Leonora's work is of the land "covered with sucking human orifices and knotted human body-hair. He did not like this vision" (246). The fact that Roland does not like this vision is important, as it suggests that she is not there to please, or to make others comfortable, but to discombobulate those around her.

Leonora's prime target for possession is LaMotte. When she tidies the grave she leaves a note held by a "green satin ribbon, water-stained and earth stained, held these fragments together" (71). Here Byatt uses earthly descriptions to show Leonora's association with the earth, and in turn, with the physical. The note that she leaves shows a form of communication with LaMotte that we do not see from the other scholars. Leonora claims to "honour" Christabel and to continue her work (71). Wells notes that we see "characters flourish in the poststructuralist climate of destabilized language, for it allows them to manipulate people and ideas in selfish ways" (Wells, "Corso, ricorso" 675-6). Stern, as well as other feminist critics in the novel, are depicted as largely subjective readers:

A Professor Stern came. From Tallahassee. She wanted to know-to know-to find out about Ellen Ash's sexual relations — with him — or anyone. I told her there was nothing of that kind in this journal. She said there must be - in the metaphors - in the omissions. We were not taught to do scholarship by studying primarily what was omitted . . Maybe what you find baffling is a systematic omission— " Nor I. I'm a textual scholar. I rather deplore the modern feminist attitude to private lives'. (241) 
Studying the omissions is characterised as an unfit means of analysis. Furthermore, Roland claims "Leonora Stern makes the whole earth read as the female body-and language - all language. And all vegetation in pubic hair" (253). The relating back to "the female body' is both physical and ideological. By finding connections to the body in the texts, Stern is able to situate herself as a woman in the feminist tradition and is able to relate to LaMotte as a suppressed- female author.

I argue that there is largesse in the way Byatt explores Leonora, she is not as hostile towards her as she perhaps has lead previous critics to believe. In the letter Leonora writes Maud there is a motherly sense of worry: "I know you haven't been happy - I think of you with great love as you progress-" (139). It also reveals a less-accusatory and even rational feminist perspectives that scholars such as Tiffin possibly overlooked. Leonora asks "why is water always seen as the female?" (139). She also says "we need to get away from the cunt as well as from the phallus" (139). This shows Leonora's willingness to review the sexual nature of her scholarship, and that her focus is not conjured solely from her personal feminist agenda. Where Maud is supposedly better able to examine with an objective stance - "'you can be psychoanalytic without being personal'-Maud said" - she is not necessarily the feminist icon of this novel (211). Although Maud is a part of a Women's Studies Centre, and converses with Leonora about her feminist readings, she is seen to distance herself from the other feminists even when there is evidence in a letter that she has encouraged Leonora's work.

Leonora's analyses are not totally unfounded. In LaMotte's story "The Glass Coffin" the wind is personified as female and there appears to be a sexualised exchange between the wind and the tailor (58). The "long, airy arms of the West Wind reached down through the trees and caught him up", and the wind is described as "shivering and clattering and trembling with her passing" as though in a sexual excitement (61). During this embrace the tailor is "against the invisible rushing breast of the long Wind, as she hurled moaning along the sky", evocative of sexual pleasure and release (61).

Leonora is certainly not without her issues, and her possessive tendencies explain a need to over-read LaMotte. In these misreadings of LaMotte is the subjective need to see in her object elements of herself, particularly with regard to claiming LaMotte to be "a lesbian feminist poet. Which she was, but not exclusively, it appears" (485). Her possessive tendencies are not malicious, however, and she becomes a more motherly figure by the end of the novel. As with the aforementioned 'othering', there is a strong sense of Britain reclaiming British literature, and conflict between American and British academia explored in the novel. 
When Leonora angers Sir George he says that she called "the state of that grave ... shocking ... A national monument" (80). What is important is that he follows this with "not her national monument" (80). As an American studying an undervalued British poet, Leonora faces othering, and distancing throughout the novel that attempts to delegitimise her studies. Yet, when discussing the letters Leonora says:

I think the letters should be in the British Library. We can all have microfilms and photocopies, the problems are only sentimental. And I'd like Christabel to have honour in her own country and Professor Blackadder here, who's the greatest living Ash scholar, to have charge of the correspondence. I'm not acquisitive, Shushila - all I want is a chance to write the best critique of these letters once they're available. The days of cultural imperialism are over. (404)

Where Leonora has shown a need to possess, and sought anyone around her to fulfil this need, including LaMotte and the grave, she ultimately shows a willingness to be a part of the collective scholarship, and to bridge American and British ties.

\section{Val and Blanche Glover}

The Game was published in 1967, 4 years after Betty Friedan's seminal feminist text The Feminine Mystique, which questioned the cultural expectation that women should "seek fulfilment [in the home] as wives and mothers" (5). Possession was first published in 1990, but due to its settings of the late 1980s and the Victorian period, as well as its close thematic relation to The Game, second-wave feminism is still prevalent through the depictions of some of the characters. Val and Blanche Glover resemble elements of Friedan's observations. The two women present contrasting images of women in the home being possessed or seeking possession. Val seeks possession by a man, and Blanche seeks possession by Christabel, and desires to possess Christabel within the home.

\section{Val}

In a novel like The Collector, collecting and being possessed is a distinctly negative trait. Possession denies this simple classification. The least-nuanced character, Mortimer Cropper, shows Byatt's similarity to Fowles in that she condemns an obsession with the object. However, Helen Wilkinson notes that "collections in Byatt's work may be negative 
and sterile, but they may also be positive and life-affirming" (96). Although she is a secondary character, Roland's girlfriend Val is one of the few characters who are never given a surname. It is also unlikely that Val is not a shortened version of a full name like Valerie, although this is not textually confirmed. What the name denotes is an incompleteness that is supported by her lack of characterisation. The name Val also conjures other words that recur in the text, such as ambivalent and value. Val lacks depth, despite the novel utilising a thirdperson narrator. When Val and Roland's home life is introduced the narration is focalised through Roland and we are given no information on Val's inner life. When Roland's PhD grant money runs out, Val becomes the main source of income for the household, doing what she calls "menial" jobs that she refuses to discuss at home (14). Val is described as having two sides: the plain one who "sat silently at home", and the "mournfully bright menial Val", who goes to work (14). This simplification of her personality into definable roles does not reflect a complex or dynamic woman. Friedan describes that "the problem" (9) that housewives were unable to name, but that all of them seemed to understand was that they "want[ed] something more than my husband and my children and my home" (20). Although Val works, she displays a similar suppression. Where much has been made of the silences and gaps in Ellen Ash's journal, Val is also silent, and serves to advance Roland's scholarly achievements. The narrator says it is "Val [who] had been, Roland was sure, partly responsible for his First" (11). We are told Roland notices that as he succeeded "Val said less and less, and when she argued, offered him increasingly his own ideas, sometimes the reverse side of the knitting, but essentially his" (12). Through her association with Roland, Val does not succeed as a scholar and instead becomes a silent object in the home. She closes herself off to Roland, so that she is ambivalent. With the name 'Val' she only becomes partly valuable.

When Blackadder "chose silence" it became the catalyst for his obsession with Ash (28). Through Ellen's silences in her journal she subverts access to her, but in this way she can construct the perfect housewife. When Val becomes silent it is a form of suppression, but what she seeks is to be possessed by someone else. She thinks that Roland and Maud are "obsessed with each other" but that it is "healthier than being obsessed with Randolph Ash" (332). This confirms the novel represents aspects of negative and positive possession. Val refuses to become obsessed with any object, making Roland keep his image of Randolph Ash in the "dark hall" when they lived together because "she wanted a bit of her life to herself without having to share it with Randolph Ash" (16). 
However, when Euan (a solicitor) enters her life it becomes clearer that Val wants to be possessed by a man, particularly a man that exudes confidence and authority. Roland never wanted to possess her, and is instead possessed by Ash and goes on to sexually possess Maud. This is an interesting take on Friedan's original argument. She wants to be val-ued and finds that with Euan. When Val reappears near the end of the novel Roland notices that she has "the shine of really expensive and well-made clothes, and more important and unmistakable, the glistening self-pleasure of sexual happiness" (432). Beatrice also notices "Val's new, slightly defiant radiance" (477). Maud notes that when she fixes "her eye on the photograph of Ash" it is beyond Roland "between him and Val" (480). This is representative of their entire relationship. Val wanted Ash to be out of their lives, but Roland is unable to do this. Through the sexual pleasure she receives in her relationship with Euan, and through finally having someone to value her, she becomes Euan's woman.

\section{Blanche Glover}

Samantha Carroll's 2008 article "Lesbian disPossession: The Apparitionalization and Sensationalization of Female Homosexuality in A. S. Byatt's Possession: A Romance" is thorough, convincing, and analyses Blanche Glover, who has "seldom been the concern of the text's critics" (358). Carroll argues "Byatt deploys techniques of erasure to "blanch" Glover out of mortal possibility" (359). This is first signified by the name which "connotes invisibility", and the implication that the women are lesbian but Byatt's refusal to confirm this (Carroll 363). I would also argue that Blanche's chastity, as with Ellen's, creates their non-existent bodies. Both women fade into the background of the poets that they loved. Carroll argues that for heterosexual love to win Blanche must be removed, although, as I argued previously, their romance is ultimately unfulfilled, neither Ash nor LaMotte possesses the other or their own child (362). Nonetheless, it is important to acknowledge the shortcomings in the representation of non-heteronormative romances in the novel, particularly the "systemic trend of lesbian erasure and debasement" (Carroll 358) that continues to evoke Coleridge's Geraldine (Carroll 364). Kathleen Renk opposes Carroll's argument of "lesbian erasure" (358) and "Jackie Buxton's claim that "Possession's plot lacks subversion because it ultimately abandons the lesbian relationship and returns to a heterosexual paradigm" (582). Renk favours viewing LaMotte and Blanche as an "antidote to acquisitive possession" and argues that through their intimacy Christabel's "art is strenthen[ed]" and she is "more productive" (581-2). In this way she suggests, "Byatt turns 
Platonic thinking on its head by creating her same-sex female couple that initially thrives as an artistic couple that seeks beauty together" (582). Renk's argument does not account for Blanche's possessive desires that do have romantic parallels. Furthermore, when Christabel is taken from her she commits suicide like a jilted lover.

What is of particular interest is the word dispossession in the title of Carroll's article, which is "the action... or fact of being dispossessed; deprivation of or ejection from a possession" (“dispossession"). This is a different form of possession compared with any other character. It manifests in the stereotypical treatment of Blanche, particularly the 'bury your gays' trope, which has homosexual characters not achieving happy endings, or being killed. It is this stereotype that emphasises how artistic expression can be fuelled by the desire to possess, and what occurs when one is dispossessed.

There is little evidence to suggest that LaMotte and Blanche consummated a sexual relationship. Carroll argues that there is a "discernible concordance between actual Victorian women's unions and the fictional Glover and LaMotte" (361). When LaMotte consoles Blanche it is with their "special ways" (47), which could be interpreted as erotic (Carroll 361). For Val and Roland, their possession of their lovers is through sexual fulfilment, and Blanche largely seems to have not been able to fulfil her own sexual desires. What is not in doubt is that their relationship is built on a passion of the mind as both women "had artistic ambitions" (Byatt 36). Furthermore, their relationship, like that of LaMotte and Ash, is one that intertwines their artistic visions, with Blanche having carved "the skilful and mysterious wood engravings which illustrate Christabel's delightful, if slightly disquieting, Tales for Innocents, and Tales Told in November, and her religious lyrics, Orisons" (36). Notably, it is only her works created with LaMotte that survive. Blanche is unable to "make an earthly [artistic] trace anywhere", other than as a pawn in uncovering Ash and LaMotte's relationship (Carroll 366). Blanche's diary “only gains significance” (Carroll 366) "when Roland Mitchell [sic] perceives in it references to the principal 'story' of Possession"- that is, the AshLaMotte affair" (Todd qtd. in Carroll 366). This is of importance because Blanche's diary is more personable than Ellen's. Blanche appears to offer unfettered access to herself and her life with Christabel, but none of the scholars are especially interested in this for what it reveals about Blanche. Roland handles it "respectfully" but does not think it has "the magnetic feel of the two letters" that he stole (43-4). Roland repeats throughout the text how the letters "were alive", and yet, on looking at a diary that could be the key to unlocking aspects of the task, Blanche's diary is not considered (50). 
Blanche's diary covers the breakfast where Ash and LaMotte first meet, but for Blanche "not much of interest was said, and certainly not by shadowy me" (44). This is also where we first learn that Blanche calls LaMotte "The Princess" (45), which has a tone of capture. Renk argues that “[i]n “alluding to Tennyson's 'The Princess' with Blanche's moniker for Christabel as the 'Princess,' Byatt seems to be deliberately underscoring how Ash is like the Prince in Tennyson's poem who intrudes on Princess Ida's all-female utopian world" (584). At the breakfast Blanche "desire[s] to be at home" and writes that she is pleased when she is "able to close our own dear front door behind us, and be gathered into the silence of our little parlour" (45). Blanche closes LaMotte in, and in doing so, locks them away from the outside world. This is also evoked in a painting Blanche is considering producing, which has imagery of imprisonment and solitude. It would be "a subject from Malory, the imprisoning of Merlin, solitude, by the damsel Nimue, or the solitary Maid of Astolat" (45). This aligns Blanche with Merlin, and Christabel with the damsel Nimue and the Maid of Astolat. There are similarities between Frederick Clegg and Blanche. Both live in a secluded home, wanting in some ways to imprison their unrequited love, but also to capture the object (subject) of their desire through artistic venture, although Blanche is a far less sadistic version of this desire.

LaMotte being "much admired" is a tremendous source of jealousy for Blanche (44). Blanche is annoyed when "a long letter" arrives and Christabel does not share the contents with her (45). Blanche's need to be both possessed and to be the possessor is revealed through the moments when she indicates that her self-worth hinges on LaMotte. When LaMotte hangs her painting, Blanche feels that it "shows up my imperfections", and she wishes she were surer of her self-worth (45-6). In her diary Blanche deteriorates in to manic anger: "Letters, letters, letters. Not for me. I am not meant to see or know" (46). It is after this that she mentions the "Prowler" (46). Roland believes this could be Ash. The use of the word prowler, meaning "one who seeks advantage by any underhand or dishonourable means; a parasite; a pilferer, impostor" ("prowler"), is particularly negative. It is as though Ash has come to claim LaMotte, to steal her from Blanche's home. Thus, while Blanche would like to think of herself as a figure of protection, she comes to be seen as a woman keeping her princess captive in a tower. The unrequited love between Blanche and LaMotte has fatal consequences. When LaMotte disappears with Ash, and Blanche's desire for mutual possession is stolen from her, she commits suicide. In some ways this is similar to Cassandra's actions in The Game. When Cassandra commits suicide it is because she has been dispossessed of her own life. The possessor imbues objects with his/her self-worth and 
life's purpose. In doing so, they are vulnerable to mental collapse when the object is taken from their possession. Blanche can no longer live when not in possession of LaMotte. 


\section{Conclusion}

In this thesis I have sought to expand on some of the critical trends in analyses of these four novels. This includes the moral debate over how to approach The Collector, and what I deem to be the deficient reading of Julia and Cassandra Corbett as a single binary being in The Game. In The French Lieutenant's Woman I examined Charles Smithson's possessive personality and the discarding of Ernestina Freeman. In the final chapter I looked at the under-examined secondary characters of Possession to broaden analysis on the novel. There are many valuable critical readings of these novels that were of benefit to my work. However, with the present distance from the publications of the novels, and the early readings that became critical waves, comes the opportunity to review and propose how to progress analyses. The thesis advocates for renewed close readings of the novels through a focus on the dominant theme of possession. In every novel there are characters either possessed, fleeing a possessor, or attempting possession. By placing these four novels in one thesis I have aimed to illuminate how fundamental possession is to all of them.

Baudrillard offers a way to review The Collector without becoming too embroiled in a moral debate. Possession is a theme that invokes morality, but by arguing that the novel is also a narrative exemplar of the process of possession, based on the plot, a discussion over right and wrong becomes almost secondary. What is interesting is how Clegg possessively views Miranda, the way that she is first formed in his mind and her eventual depersonalisation and death. The novel portrays an enactment of possession, and was thus well suited as an introduction to how Baudrillard's theory of possession can apply to humans, and to initiate a discussion on the theme.

The Game probes the power of fiction and the capacity to possess our creations. Julia does not perform a physical possession, but her psychological treatment of Cassandra is similar to Clegg's possession of Miranda. Julia meditates on Cassandra, creating her in her mind. She then infiltrates Cassandra's life, dehumanises her, and goes on to concretise her vision of 'Cassandra' in the character of Emily. This parallels Clegg's dehumanisation of Miranda in the pornographic photos. Lastly, Cassandra loses her agency when this process leads her to suicide. Julia's character, Emily, survives Cassandra and so Julia possesses her sister as a character in a novel, along with Cassandra's diaries that are left behind as more fodder for her writing. My reading of The Collector and The Game are complementary. By placing these novels in succession I suggest that the possessive process is fundamentally the same, even though it presents itself through different forms. Here we have one novel on 
physical possession and another one on mental possession but at the core of each is one possessor and one possessed.

In considering TFLW and Possession, Baudrillard's theory becomes too reductive to describe what is occurring, but it does still act as a way to locate what is sought by the possessors. We can track Fowles's progression from a singular possessive character to multiple possessors in TFLW. In my reading of TFLW, noting Charles Smithson's possessive personality is key to dissecting his relationships in the novel. This chapter looked at Ernestina Freeman as a woman possessed by her social position, and reviewed the conflicting readings of Sarah Woodruff.

In Possession all of the characters look to possession as a way to counter their feelings of lack, as though authority will fill their personal void. I pursued the secondary characters as a way to broaden the previous readings of the theme of possession that had focussed on the four main characters. The chapter also integrated the largely unexplored Val and Blanche. The novel complicates how we read possession as there is no definitive message. Possession in Possession can be positive when it is mutual, and negative when it is obsessive.

The influence of TFLW on the writing of Possession has been well documented, but The Collector had no acknowleged influence on The Game. Even when scholars compare the two later novels none have thus far noted the authors' creative preludes, nor that the early novels are similar. The final question this thesis raises is why both of these authors have been concerned with possession, in similar ways, from the beginning of their careers. To delve into this question within the chapters would have required extensive contextual work. This would have diverted from my main objectives of reviewing criticism on the novels and producing a close analysis to reveal key character dynamics. The question is raised, nonetheless, and having reached this conclusion I will propose a final point for consideration.

These four novels by Byatt and Fowles, three of which were published in the sixties, substantiate Sebastian Groes's argument that the sixties can be generally characterised as a decade where received "[f]orms of representation came under intense scrutiny . . . because of the increasing socio-cultural complexity and fragmentation of society" (38), particularly "power over women" (57). Fiction of this period was "thinking about . . . issues, such as the nature of reality, changing ways of representation of that reality, [and] the nature of the self" (Groes 73). In essence, we could say that the sixties was a time of destabilisation in societal structures and the established means of understanding the self and others. The theme of possession is connected to these anxieties. Both authors are exemplary of their time through 
their use of possession to construct characters that desire to understand others based on their own world view. The central theme of these novels accounts for a dread over unfixed meanings, and how a possessor reacts against this. The Collector and The Game show an early introduction to this. When both authors expand in the latter two novels it showcases the many ways that people possessively navigate relationships.

These novels are about the ways in which characters try to create stability in an unstable world through acts of possession. These acts are used by characters to create their ideal selves and to reorganise others: possession is an exertion of power. The possessor tries to be the God who, in the biblical tradition, "created mankind in His own image" (The Bible: Authorized King James Version, Gen. 2.27). 


\section{Works Cited}

“abstraction, n." OED Online. 3rd ed, Mar. 2017. Oxford University Press, www.oed.com/view/Entry/766?redirectedFrom=abstraction\&. Accessed 6 Apr. 2017. Acheson, James. “John Fowles's The French Lieutenant's Woman.” A Companion to the British and Irish Novel 1945-2000, edited by Brian W. Shaffer, Blackwell Publishing, 2005.

Adams, Ann Marie. "Death Authors, Born Readers, and Defunct Critics: Investigating Ambiguous Critical Identities in A.S. Byatt's 'Possession'.” The Journal of Midwest Modern Language Association, vol. 36, no. 1, 2003, pp. 107-124.

Alfer, Alexa, and Amy J. Edward de Campos. A.S. Byatt: Critical Storytelling. Manchester University Press, 2010.

Alighieri, Dante. The Divine Comedy of Dante Alighieri: Volume 3: Paradiso. Translated and Edited by Robert M. Durling, Oxford University Press, 2011.

Ashenburg, Katherine. “Sibling Rival.” Toronto Life, Oct. 2003, p. 50.

Aubrey, James. John Fowles: a reference companion. Greenwood Press, 1991.

Austen, Jane. Emma. 1815. Wordsworth Editions Ltd, 1997.

Bal, Mieke. "Telling Objects: A Narrative Perspective on Collecting." The Cultures of Collecting, edited by Roger Cardinal and John Elsner, Reaktion Books, 1994.

Barber, Susan and Richard Messer. "Tire French Lieutenant's Woman and Individualization.” Literature /Film Quarterly, vol. 12, no. 4, 1984, pp. 225-9.

Barnum, Carol M. The fiction of John Fowles: a myth for our time. Penkevill Publishing Company, 1988.

Baudrillard, Jean. "The System of Collecting." The Cultures of Collecting. Translated by Roger Cardinal, edited by Roger Cardinal and John Elsner, Reaktion Books, 1994.

Binns, Roland. "John Fowles: Radical Romancer." Critical Essays on John Fowles, edited by Ellen Pifer, G.K. Hall, 1986.

Bixby, Peter. Over Character's Shoulder: Reading Embedded Texts In Fictional Worlds, Dissertation, Indiana University, 1999.

Boccardi, Mariadele. A.S. Byatt. Palgrave Macmillan, 2013.

Bourdieu, Pierre. Distinction: a social critique of the judgement of taste. Translated by Richard Nice, Harvard University Press, 2009.

Byatt, A.S. Angels and Insects: Two Novellas. 1992. Vintage, 1994.

---. “Art Work.” The Matisse Stories. 1993, pp. 29-90. 
---. “A.S. Byatt in Conversation.” P. N. Review, By Nicolas Tredell, vol. 17, no. 3, 1990, pp. 24-28.

---. The Biographer's Tale. Vintage, 2001.

---. The Game. 1967. Vintage, 1999.

---. “The July Ghost.” Sugar and Other Stories. 1987. Vintage, 1995, pp. 39-56.

---. On Histories and Stories: Selected Essays. Harvard University Press, 2001.

---. Possession. 1990. Knopf Publishing Group, 2009.

---. The Shadow of the Sun. 1964. Vintage, 1991.

Brindle, Kym. Epistolary Encounters in Neo-Victorian Fiction: Diaries and Letters. Palgrave Macmillan, 2013.

Buchberger, Michelle Phillips. "John Fowles's Novels of the 1950s and 1960s." The Yearbook of English Studies, vol. 42, 2012, pp. 132-150.

Caine, Barbara. English Feminism, 1780-1980. Oxford University Press, 1997.

Caird, Mona. The Morality of Marriage And Other Essay On The Status And Destiny Of Women. George Redway, 1897.

Campbell, Jane. A.S. Byatt and the Heliotropic Imagination. Wilfrid Laurier University Press, 2004.

Carroll, Samantha J. "Lesbian dispossession: The Apparitionalization and Sensationalization of Female Homosexuality in A. S. Byatt's Possession: A Romance." Critique: Studies in Contemporary Fiction, vol. 49, no.4, 2008, 357-378.

Cooper, Pamela. The fictions of John Fowles: power, creativity, femininity. University of Ottawa Press, 1991.

Conradi, Peter. John Fowles. Methuen, 1982.

Creighton, Joanna. "Sisterly Symbiosis: Margaret Drabble's The Waterfall and A.S. Byatt's The Game." Mosaic: An Interdisciplinary Critical Journal, vol. 20, no.1, 1987, pp. $15-29$.

“demonic, adj. and n." OED Online. 3rd ed, Mar. 2017. Oxford University Press, www.oed.com/view/Entry/49810?redirectedFrom=demonic\#eid. Accessed 6 Apr. 2017.

“dispossession, n.” OED Online. 3rd ed, Mar. 2017. Oxford University Press, www.oed.com/view/Entry/55133?redirectedFrom=dispossession\#eid. Accessed 6 Apr. 2017.

Docherty, Thomas. "A Constant Reality: The Presentation of Character in the Fiction of John Fowles." Novel: A Forum on Fiction, vol. 14, no. 2, 1981, pp. 118-34. 
Dodson, Mary Lynn. “The French Lieutenant's Woman: Pinter and Reisz's Adaptation of Fowles's Adaptation.” Literature/Film Quarterly, vol. 26, no. 4, 1998, pp. 296-303.

Duncker, Patricia. “On Writing Neo-Victorian Fiction”. English, vol. 63, no. 243, 2014, pp. 253-274.

“earnest, n.” OED Online. 3rd ed, Mar. 2017. Oxford University Press, www.oed.com.helicon.vuw.ac.nz/view/Entry/59001?rskey=jmtAlg\&result=1\#eid. Accessed 6 Apr. 2017.

Engels, Friedrich. The Condition of the Working Class in England. 1884. Edited by Victor Kiernan, Penguin Books, 2005.

“episode 102 - A.S. Byatt - part 01.” YouTube, uploaded by The Drexel InterView Archives, 16 Jun. 2001, www.youtube.com/watch?v=TkcLdrUkKWc\&t=47s.

Fletcher, Lisa. "Historical Romance, Gender, and Heterosexuality: John Fowles's The French Lieutenant's Woman and A.S. Byatt's Possession." Journal of Interdisciplinary Gender Studies, vol. 7, no. 1/2, 2003, pp. 26-42.

Fowles, John. “An Unholy Inquisition.” Conversations with John Fowles, By Dianne L.

Vipond, University Press of Mississippi Jackson, 1999.

---. "Fowles on Fowles." Conversations with John Fowles, By Susana Onega, University

Press of Mississippi Jackson, 1999.

---. "John Fowles: The Art of Fiction CIX." Conversations with John Fowles, By James R.

Baker, University Press of Mississippi Jackson, 1999.

---. "Notes on an Unfinished Novel." The Novel Today: Contemporary Writers on Modern Fiction, edited by Malcom Bradbury, Manchester University Press, 1977.

---. The Aristos. 1968. Vintage, 2001.

---. The Collector. 1963. Vintage, 2004.

---. The French Lieutenant's Woman. 1969. Vintage, 2004.

---. The Magus. 1977. Vintage, 2004.

Franken, Christien. A.S. Byatt: Art, Authorship, Creativity. Palgrave Macmillan, 2001.

Friedan, Betty. The Feminine Mystique. 1963. Penguin Classics, 2010.

Groes, Sebastian. British Fiction of the Sixties. Bloomsbury Publishing, 2016.

Hadley, Louisa. Neo-Victorian Fiction and Historical Narrative: The Victorians and Us. Palgrave Macmillan, 2010.

Hegel, Georg Wilhelm Friedrich. Phenomenology of Spirit. Translated by A.V. Miller, Motilal Banarsidass Publishers, 1998. 
Hennelly Jr, Mark M. “'Repeating Patterns' and Textual Pleasures: Reading (in) A. S. Byatt's Possession: A Romance." Contemporary Literature, vol. 44, no. 3, 2003, pp. 442-71.

Holmes, Frederick M. "The Historical Imagination and the Victorian Past: A.S. Byatt's Possession.” English Studies in Canada, vol. 20, 1994, 319-34.

---. “The Novel, Illusion and Reality: The Paradox of Omniscience in 'The French

Lieutenant's Woman'." The Journal of Narrative Technique, vol. 11, no. 3, 1981, pp. 184-198.

Huffaker, Robert. John Fowles. Twayne Publishers, 1980.

Jódar, Andrés Romero. “"A Stranger in a Strange Land: An Existentialist Reading Of

Frederick Clegg In The Collector By John Fowles." Atlantis: revista de la Asociación Española de Estudios Anglo-Norteamericanos, vol. 28, no. 1, 2006, pp. 45-55.

Kaplan, Bruce Eric. Cartoon. The New Yorker, 26 Oct. 1998.

Kelly, Kathleen Coyne. A.S. Byatt. Twayne, 1996.

Landrum, David W. "Rewriting Marx: Emancipation and Restoration in The French Lieutenant's Woman.” John Fowles Issue, vol. 42, no. 1, 1996, pp. 103-113.

Laughlin, Rosemary M. "Faces of Power in the Novels of John Fowles." Critique, vol. 13, no. 3, 1987, pp. 71-88.

Lenz, Brooke. John Fowles: visionary and voyeur. Rodopi, 2008.

Levmore, Saul. "Kidnap, Credibility, and The Collector." Fatal Fictions: Crime and Investigation in Law and Literature, edited by Alison L. LaCroix, Richard H. McAdams and Martha C. Nussbaum, Oxford University Press, 2017.

Limond, Kate. "“A solid metaphoric extension of his Self” : thing theory and collecting in A.S. Byatt's fiction," Nebula, vol. 6, no.4, 2009, pp.56-77.

Loveday, Simon. The Romances of John Fowles. Macmillan, 1986.

Lynch, Richard. "Symbolic Narratives: The Dangers Of Being An Intertextualy Inclined Character." Studies in the Novel, vol. 41, no.2, pp. 224-240.

Marais, Mike. "'I am infinitely strange to myself”: Existentialism, the Bildungsroman, and John Fowles's The French Lieutenant's Woman." Journal of Narrative Theory, vol. 44, no. 2, 2014, pp. 244-266.

Merkin, Daphne. "Dame of the British Interior.” The New York Times. 11 Sept. 2009, www.nytimes.com/2009/09/13/magazine/13Drabble-t.html. Accessed 15 Nov. 2016.

Mitchell, Kate. History and Cultural Memory in Neo-Victorian Fiction: Victorian Afterimages, Palgrave MacMillan, 2010. 
Mitchell, W.J.T. "Representation.” Critical Terms for Literary Study, edited by Frank Lentricchia and Thomas McLaughlin, The University of Chicago Press, 1990, pp. 1122.

Mountford, Fiona. "The Collector, theatre Review: John Fowles adaptation is beset by listlessness and uncertainty." Evening Standard, 5 Aug. 2016, www.standard.co.uk/goingout/theatre/the-collector-theatre-review-john-fowlesadaptation-is-beset-by-listlessness-and-uncertainty-a3312641.html. Accessed 5 Oct. 2016.

Murphy, Lynne. 'Linguistics Explains Why Trump Sounds Racist When He says 'the' African Americans.” Quartz, 11 Oct. 2016, qz.com/806174/second-presidentialdebate-linguistics-explains-why-donald-trump-sounds-racist-when-he-says-theafrican-americans/. Accessed 19 Oct. 2016.

Nodelman, Perry. "John Fowles's Variations In The Collector." Contemporary Literature, vol. 28, 1987, pp. 332-46.

Olmstead, A.D. “Collecting: Leisure, Investment or Obsession?” Journal of Social Behavior and Personality, vol. 6, no. 6, 1991, pp. 287-306.

Olshen, Barry. John Fowles. F. Ungar, 1978.

Palmer, William. "John Fowles and the Crickets." MFS Modern Fiction Studies, vol. 31, no. 1, 1985, pp. 2-13.

---. The Fiction of John Fowles: Tradition, Art, and the Loneliness of Selfhood. University of Missouri Press, 1974.

Pearce, Susan M. On Collecting: An Investiagation Into Collecting In The European Tradition. Routledge, 1999.

Pifer, Ellen. Introduction. Critical Essays on John Fowles, edited by Ellen Pifer, G.K. Hall \& Co, 1986, pp. 1-18.

Poulet, George. "Criticism and the Experience of Interiority." Reader-Response Criticism: From Formalism to Post-Structuralism. The John Hopkins University Press, 1980.

“prowler, n.” OED Online. 3rd ed, Mar. 2017. Oxford University Press, www.oed.com/view/Entry/153548?redirectedFrom=prowler\#eid. Accessed 6 Apr. 2017.

“psyche, n.” OED Online. 3rd ed, Mar. 2017. Oxford University Press, www.oed.com/view/Entry/153848? redirectedFrom=psyche\#eid. Accessed 6 Apr. 2017. 
Rankin, Elizabeth. "Cryptic Coloration in "The French Lieutenant's Woman"”. The Journal of Narrative Technique, vol 3, no. 3, 1973, pp. 193-207.

Renk, Kathleen. 'Erotic Possession, the 'Phantasm,' and Platonic Love in Two NeoVictorian Novels". Critique, vol. 56, 2015, pp. 576-585.

Rhys, Jean. Wide Sargasso Sea. 1966. Longman, 2001.

Rohland-Le, Andrea. The Spaces Between: A.S. Byatt and Postmodern Realism, Dissertation, Universite de Montreal, 1999.

Rudaitytë, Regina. “(De)construction of the postmodern in A.S. Byatt's Novel Possession”. Literatûra, vol. 49, no. 5 (2007), pp. 116-122.

Salami, Mahmoud. John Fowles's Fiction and the Poetics of Postmodernism. Fairleigh

Dickinson University Press, 1992.

Shakespeare, William. The Tempest. 1611. Oxford University Press, 2008.

Shatro, Bavjola. “"The Collector' as experience of Eros and sexuality in Vladimir Nabokov's 'Lolita' and John Fowles' 'The Collector'.” European Scientific Journal, vol. 8 , no. 29,2012 , pp. 64-78.

Shiffman Adrienne. “'Burn What They Should Not See': The Private Journal as Public Text in A. S. Byatt's Possession”. Tulsa Studies in Women's Literature, vol. 20, no. 1, 2001, pp. 93-106.

Showalter, Elaine. “The Professor Wore Prada.” Vogue, Dec. 1997, pp. 80, 86, 92.

St. Clair, Pamela. Du(e)l Personalities: A Rhetorical Analysis Of The Split Female Vision In A.S. Byatt's The Game, MA thesis, Southern Connecticut State University, 2001.

Stickney Ellis, Sarah. The Women of England. Appleton \& co, 1839.

$\mathrm{Su}$, John J. "Fantasies of (Re)collection: Collecting and Imagination in AS Byatt's

Possession: A Romance.” Contemporary Literature, vol. 45, no. 4, 2004, pp. 684-712. Thackery, William Makepeace. Vanity Fair. 1848. Wordsworth Editions Limited, 2001. The Bible: Authorized King James Version with Apocrypha. Oxford University Press, 2008. Tiffin, Jessica. "Ice, Glass, Snow: Fairy Tale as Art and Metafiction in the Writing of A. S. Byatt". Marvels \& Tales, vol. 20, no. 1, 2006, pp. 47-67.

Todd, Richard. A.S. Byatt. Northcote House Publishers Ltd, 1997.

Vergil. "Book four." The Aeneid. Translated by Sarah Ruden, Yale University, 2008, ebookcentral.proquest.com/lib/VUW/detail.action?docID=3420452. Accessed 19 Jan. 2017. 
Wagner, Jill E. "Class consciousness, critter collecting, and climatic conditions: postVictorian existentialism in the 'morphing' Victorian scientist." Victorian Newsletter, vol. 112,2007 , pp. 32-50.

Wells, Lynn. “A.S. Byatt's Possession: A Romance.” A Companion to the British and Irish Novel 1945 - 2000, edited by Brian W. Shaffer, Blackwell Publishing, 2005.

---. "Corso, ricorso: Historical repetition and cultural reflection in A. S. Byatt's Possession: A Romance”. MFS Modern Fiction Studies, vol. 48, no. 3, 2002, pp. 668-693.

Wendorf, Robert. Literature of Collecting \& Other Essays. Oak Knoll Press and the Boston Athenaeum, 2008.

Wilde, Oscar. The Importance of Being Earnest and Other Plays. Oxford: Oxford University Press, 1998.

Wilkinson, Helen. "Mr Cropper and Mrs Brown: good and bad collectors in the work of A.S. Byatt and other recent fiction". Experiencing Material Culture in the Western World, edited by Susan M. Pearce, Leicester University Press, 1997.

Williams, Zoe. "Beauty and the Beast: feminist or fraud?" theguardian, 19 Mar. 2017, www.theguardian.com/film/2017/mar/19/beauty-and-the-beast-feminist-or-fraud. Accessed 22 Mar. 2017.

Wolfe, Peter. John Fowles, Magus and Moralist. Bucknell University Press, 1976.

Woodcock, Bruce. Male Mythologies: John Fowles and Masculinity. Harvester, 1984. 